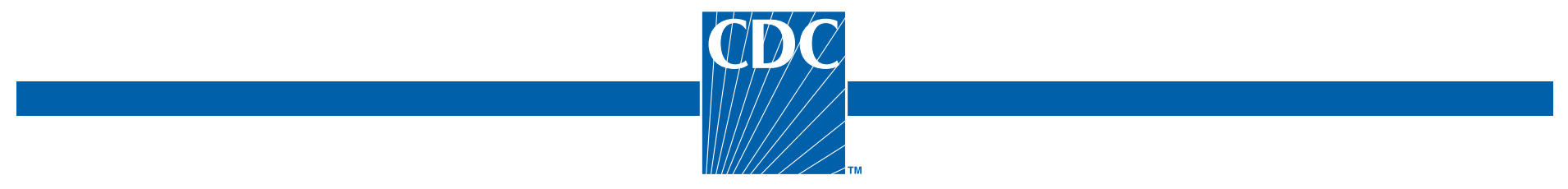

\title{
MMWR \\ Morbidity and Mortality Weekly Report
}

Weekly

December 12, 2003 / Vol. 52 / No. 49

\section{Update: Influenza Activity — United States, 2003-04 Season}

Influenza began circulating in the United States unusually early this season, and influenza activity nationwide is expected to increase. Cases of severe disease, including deaths, have been reported in children. This report summarizes influenza activity in the United States during the weeks ending October 4December 6, 2003*. During the week ending December 6, influenza activity was reported to CDC as widespread in 24 states (Figure). The early season and the unusually high and persistent demand for vaccine have resulted in a decreasing

$\bar{*}$ Data reported as of December 5 .

FIGURE. States in which estimated influenza activity has been reported by state epidemiologists, by level of activity ${ }^{*}$ - United States, November 23-29, 2003

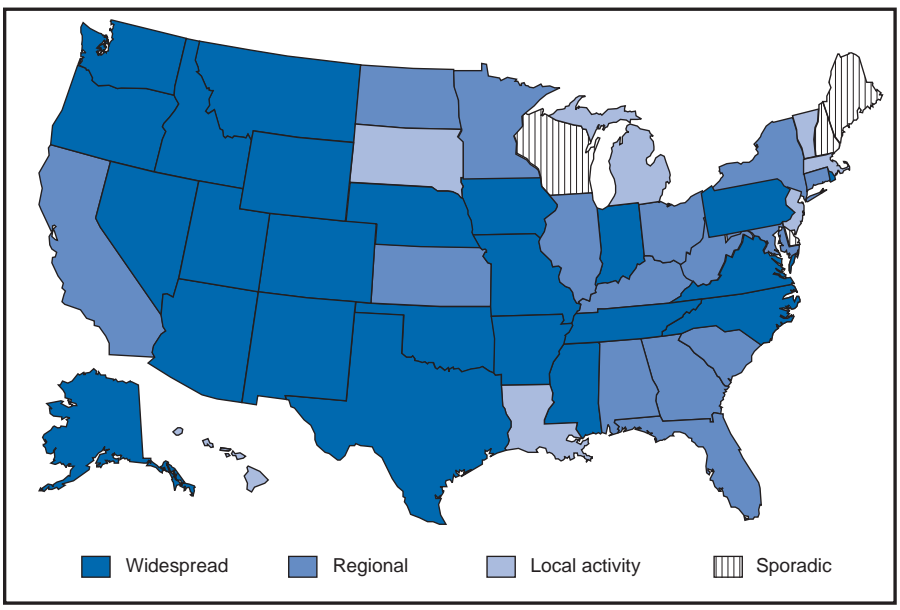

* Levels of activity are 1) no activity, 2) sporadic-small numbers of laboratory-confirmed influenza cases or a single influenza outbreak reported but no increase in cases of ILI, 3) local-outbreaks of influenza or increases in influenza-like illness (ILI) cases and recent laboratoryconfirmed influenza in a single region of a state 4) regional-outbreaks of influenza or increases in ILI cases and recent laboratory-confirmed influenza in at least two but less than half the regions of a state, and 5) widespread-outbreaks of influenza or increases in ILI cases and recent laboratory-confirmed influenza in at least half the regions of a state. supply of trivalent inactivated vaccine. Emphasis should be placed on vaccinating persons at high risk for complications from influenza, including healthy children aged 6-23 months. Healthy persons aged 5-49 years who wish to receive vaccine should consider being vaccinated with the intranasally administered live, attenuated influenza vaccine (LAIV), a substantial supply of which remains available.

\section{National Surveillance}

CDC conducts national influenza surveillance by monitoring 1) viruses through a system of approximately 120 World Health Organization (WHO) and National Respiratory and Enteric Virus Surveillance System (NREVSS) laboratories, 2) visits for influenza-like illness (ILI) ${ }^{\dagger}$ through the U.S. Influenza Sentinel Providers Surveillance Network, 3) the percentage of U.S. deaths attributable to pneumonia and influenza (P\&I) reported through the 122 Cities Mortality Reporting System, and 4) estimated levels of influenza activity reported to CDC by state and territorial epidemiologists. CDC also receives reports from clinicians and local health officials on influenza outbreaks and cases nationwide.

${ }^{\dagger}$ Temperature of $>100.0^{\circ} \mathrm{F}\left(37.8^{\circ} \mathrm{C}\right)$ and cough and/or sore throat in the absence of a known cause other than influenza.

INSIDE

1202 Revised U.S. Surveillance Case Definition for Severe Acute Respiratory Syndrome (SARS) and Update on SARS Cases - United States and Worldwide, December 2003

1206 Reptile-Associated Salmonellosis - Selected States, 1998-2002

1209 Tuberculosis Outbreak Among Homeless Persons King County, Washington, 2002-2003

1210 Notices to Readers 
The $M M W R$ series of publications is published by the Epidemiology Program Office, Centers for Disease Control and Prevention (CDC), U.S. Department of Health and Human Services, Atlanta, GA 30333.

\section{SUGGESTED CITATION}

Centers for Disease Control and Prevention. [Article Title]. MMWR 2003;52:[inclusive page numbers].

\section{Centers for Disease Control and Prevention}

Julie L. Gerberding, M.D., M.P.H.

Director

Dixie E. Snider, M.D., M.P.H.

(Acting) Deputy Director for Public Health Science

Susan Y. Chu, Ph.D., M.S.P.H.

(Acting) Associate Director for Science

Epidemiology Program Office

Stephen B. Thacker, M.D., M.Sc. Director

Office of Scientific and Health Communications John W. Ward, M.D. Director

Editor, MMWR Series

Suzanne M. Hewitt, M.P.A. Managing Editor, MMWR Series

Jeffrey D. Sokolow, M.A. (Acting) Lead Technical Writer/Editor

Jude C. Rutledge

Teresa F. Rutledge

Douglas W. Weatherwax

Writers/Editors

Lynda G. Cupell

Malbea A. LaPete

Visual Information Specialists

Kim L. Bright, M.B.A.

Quang M. Doan, M.B.A.

Erica R. Shaver

Information Technology Specialists

Division of Public Health Surveillance and Informatics

Notifiable Disease Morbidity and 122 Cities Mortality Data Robert F. Fagan

Deborah A. Adams

Felicia J. Connor

Lateka Dammond

Donna Edwards

Patsy A. Hall

Pearl C. Sharp

\section{Influenza Virus Surveillance}

For the weeks ending October 4-December 6, WHO and NREVSS collaborating laboratories in the United States tested 24,906 respiratory specimens for influenza viruses; 6,751 (27.1\%) were positive. During the same period, the weekly percentages of respiratory specimens testing positive for influenza viruses increased from $1.4 \%$ to $37.1 \%$. During the 2000-01, 2001-02, and 2002-03 influenza seasons, the peak percentages of specimens testing positive for influenza ranged from $23.2 \%$ to $26.4 \%$. During the $1999-00$ influenza season, when influenza $\mathrm{A}(\mathrm{H} 3 \mathrm{~N} 2)$ viruses predominated, the peak weekly percentage of specimens testing positive was $30.9 \%$ (1; CDC, unpublished data, 2003).

Of the 6,751 positive isolates, $6,716(99.5 \%)$ were influenza $A$ viruses, and $35(0.5 \%)$ were influenza $B$ viruses. Of the 6,716 influenza A viruses, 1,255 (18.7\%) have been subtyped; 1,254 (99.9\%) were influenza A (H3N2) viruses, and one $(0.1 \%)$ was an influenza $\mathrm{A}(\mathrm{H} 1)$ virus. As of December 6 , a total of 47 states and all nine surveillance regions had reported laboratory-confirmed influenza.

CDC has characterized antigenically 215 influenza viruses that were collected and submitted by U.S. laboratories since October 1. Of these, 212 were influenza A (H3N2) viruses, and one was an influenza $\mathrm{A}(\mathrm{H} 1)$ virus. Of the 212 influenza A (H3N2) viruses, 54 (25\%) were similar antigenically to the vaccine strain A/Panama/2007/99 (H3N2), which is contained in this season's vaccine, whereas 158 (75\%) were similar antigenically to A/Fujian/411/2002, a drift variant of A/Panama/2007/99.

\section{ILI Surveillance}

During the weeks ending October 4-December 6, the weekly percentages of patient visits ${ }^{\S}$ to approximately 1,000 sentinel providers nationwide for ILI increased from $0.9 \%$ to $5.1 \%$, which is above the national baseline ${ }^{9}$ of $2.5 \%$. During the 2000-01, 2001-02, and 2002-03 influenza seasons, the peak weekly percentages of patient visits for ILI ranged from $3.3 \%$ to $4.4 \%$. During the $1999-00$ season, the peak weekly percentage for patient visits for ILI was 7.1\% (1; CDC, unpublished data, 2003).

\section{P\&I Mortality Surveillance}

During the week ending December 6, P\&I accounted for $7.0 \%$ of all deaths reported through the 122 Cities Mortality

\footnotetext{
${ }^{\$}$ National and regional percentages of patient visits for ILI are weighted on the basis of state population.

' Calculated as the mean percentage of visits for ILI during noninfluenza weeks, plus two standard deviations. Wide variability in regional data precludes calculating region-specific baselines and makes it inappropriate to apply the national baseline to regional data.
} 
Reporting System. The epidemic threshold** for that week was $7.6 \%$. Since the week ending October 4 , the weekly percentage of P\&I deaths has been below the epidemic threshold. The percentage of P\&I deaths exceeded the epidemic threshold for zero weeks during the 2002-03 influenza season, for 9 weeks during the 2001-02 season, and for 10 weeks during the 2000-01 influenza season. During the 1999-00 influenza season, the percentage of P\&I deaths exceeded the epidemic threshold for 15 weeks ( 1 ; CDC, unpublished data, 2003).

\section{Activity Reported by State and Territorial Epidemiologists}

During the week ending December 6, influenza activity ${ }^{\dagger \dagger}$ was reported as widespread in 24 states (Alaska, Arizona, Arkansas, Colorado, Idaho, Indiana, Iowa, Mississippi, Missouri, Montana, Nebraska, Nevada, New Mexico, North Carolina, Oklahoma, Oregon, Pennsylvania, Rhode Island, Tennessee, Texas, Utah, Virginia, Washington, and Wyoming), regional in 15 states (Alabama, California, Connecticut, Florida, Georgia, Illinois, Kansas, Kentucky, Maryland, Minnesota, New York, North Dakota, Ohio, South Carolina, and West Virginia) and New York City, and local in six states (Louisiana, Massachusetts, Michigan, New Jersey, South Dakota, and Vermont) and the District of Columbia. Sporadic influenza activity was reported in five states (Delaware, Hawaii, Maine, New Hampshire, and Wisconsin) and Guam.

\section{Reports of Severe Illness and Deaths}

Pediatric cases. CDC has received reports of severe complications of influenza occurring in young infants, school-age children, and adolescents. Complications have included encephalopathy, seizures, dehydration with severe hypotension, respiratory failure requiring mechanical ventilation, and secondary bacterial pneumonia, including necrotizing pneumonia with community-associated methicillin-resistant Staphylococcus aureus (CA-MRSA). Three deaths (an infant aged 20 months with underlying reactive airways disease, a previously healthy infant aged 22 months, and a previously

\footnotetext{
** The expected baseline proportion of P\&I deaths reported by the 122 Cities Mortality Reporting System is projected by using a robust regression procedure that applies a periodic regression model to the observed percentage of deaths from P\&I during the previous 5 years; the epidemic threshold is 1.645 standard deviations above the seasonal baseline percentage (2).

†† Levels of activity are 1) no activity, 2) sporadic — small numbers of laboratoryconfirmed influenza cases or a single influenza outbreak reported but no increase in cases of ILI, 3) local - outbreaks of influenza or increases in ILI cases and recent laboratory-confirmed influenza in a single region of a state, 4) regionaloutbreaks of influenza or increases in ILI cases and recent laboratory-confirmed influenza in at least two but less than half the regions of a state, and 5) widespread-outbreaks of influenza or increases in ILI cases and recent laboratory-confirmed influenza in at least half the regions of a state.
}

healthy child aged 16 years) have been associated with secondary pneumonia caused by CA-MRSA. Other influenzarelated deaths not related to CA-MRSA in children have occurred. Fatal cases reported to CDC are being investigated by local and state health authorities. Laboratory testing has confirmed influenza A virus infection in these fatal cases; antigenic characterization is pending. The vaccination status of the majority of the deceased children has not been determined.

Pregnant women. In Texas, 88 pregnant women had laboratory-confirmed influenza A infections. Symptoms included fever, cough, and profound sinus tachycardia (i.e., 150-170 beats per minute) that resolved subsequently. One patient required intensive care for bilateral pneumonia and myocarditis. Of the 88 patients, two $(2.3 \%)$ had been vaccinated 2 and 10 days before admission, respectively. No influenzaassociated maternal deaths occurred; one case of fetal loss occurred but was not attributed to maternal influenza infection. The majority of the 88 cases were associated with influenza A infection; however, influenza $\mathrm{B}$ viruses also were detected.

Reported by: S Harper, MD, T Uyeki, MD, E Murray, MSPH, $L$ Brammer, MPH, J Wright, DVM, K Fukuda, MD, N Cox, PhD, Div of Viral and Rickettsial Diseases; C McDonald, Div of Healthcare Quality Promotion, National Center for Infectious Diseases; M Wharton, MD, Epidemiology and Surveillance Div, National Immunization Program, CDC.

Editorial Note: Influenza seasons can vary substantially in terms of timing and pattern of onset, peaking, decline, and overall severity. In the United States, the 2003-04 influenza season began unusually early, with community activity first reported in early October, followed by continued spread of influenza activity during the weeks ending October 4 December 6. National activity levels have not yet peaked, and neither the duration of activity nor the season's eventual magnitude is known. As of December 6, influenza A (H3N2) viruses predominated in the United States, but different influenza viruses might predominate later in the season. Influenza seasons dominated by A (H3N2) viruses (e.g., those in 1996-97, 1997-98, and 1998-99) typically are associated with high levels of severe illness and deaths (3). No evidence exists to indicate that the $\mathrm{A} / \mathrm{Fujian}$-like viruses in circulation are more virulent than other influenza A (H3N2) viruses. However, reports of severe pediatric illnesses and deaths underscore the severe consequences that influenza infections can cause in children (4).

Cases of sudden death associated with influenza in previously healthy children also were reported in the United States during the 2002-03 season (4; CDC unpublished data, 2003). Although the pathophysiology of sudden deaths associated 
with influenza in children is unknown, atypical symptoms (e.g., abdominal pain, absence of fever, and mild respiratory symptoms) have been reported.

Encephalopathy is another severe and potentially underrecognized complication of influenza in children (5). One case so far this season has resulted in the death of a patient (CDC, unpublished data, 2003). Patients might report high fevers, seizures, headaches, abnormal mental status, and/or confusion and do not always exhibit classic influenza symptoms. Cases have been reported among young children and schoolaged children, including adolescents. Suspected cases should be reported to CDC at telephone, 404-639-0277 or 404-6392893; fax, 404-639-3866; or e-mail, tmu0@cdc.gov or nib9@cdc.gov.

Although secondary bacterial pneumonia is a common complication of influenza infection, $S$. aureus typically occurs in a minority of such cases. Clinical and laboratory features of S. aureus pneumonia are similar to other types of community-acquired pneumonia $(6,7)$. Clinicians should be aware that CA-MRSA can be a cause of community-acquired pneumonia. Treatment for pneumonia after influenza infection should be guided by bacterial culture results when possible. Aspirin and other salicylate-containing medications should not be administered to children with fever and respiratory illness (1).

Pregnant women are at higher risk than nonpregnant women for having complications secondary to influenza. Pregnant women who will be in their second or third trimester during influenza season should be vaccinated against influenza (8).

So far this season, influenza A/Fujian/411/2002-like viruses are predominating in the United States. This strain differs from the influenza A (H3N2) virus contained in the 2003-04 vaccine (i.e., A/Panama/2007/99). The A/Fujian-like viruses are antigenic drift variants of the A/Panama strain and were detected by global surveillance early this year but too late for inclusion in the current influenza vaccine. Hemagglutination inhibition testing using postinfection ferret sera indicates that antibodies to the A/Panama vaccine virus cross-react with A/Fujian-like viruses; therefore, current influenza vaccines should provide some protection against A/Fujian-like viruses. However, the level of protection remains uncertain until vaccine effectiveness studies are completed. The vaccine also contains A/New Caledonia/20/99 (H1N1)-like and B/Hong Kong/330/2001-like viruses and should protect persons who are vaccinated against these viruses if they circulate more widely later in the season.

Approximately 83.4 million doses of influenza vaccine, including inactivated influenza vaccine made by two manufacturers and LAIV made by a third manufacturer, were produced for the 2003-04 influenza season. All doses of trivalent inacti- vated vaccine appear to have been sold by the manufacturers and their major distributors. Trivalent inactivated vaccine remains available from physicians' offices and in other settings. As of December 9, a total of 3.9 million doses of LAIV were available from the manufacturer (Wyeth Pharmaceuticals, Collegeville, Pennsylvania, telephone 800-358-7443).

To ascertain the availability of influenza vaccine, CDC conducted a survey of state and urban area immunization programs. As of December 3, a total of 28 states had redistributed influenza vaccine from health-care providers and public immunization clinics that had excess supplies to those that needed vaccine. In addition, 34 states had influenza vaccine inventory that had not been distributed. However, in an average year, $<10 \%$ of influenza vaccine is purchased by state health departments.

Influenza antiviral medications are available for use in adults and children. Four prescription antiviral medications (i.e., amantadine, rimantadine, oseltamivir, and zanamivir) are approved for treatment of influenza A virus infections. Oseltamivir and zanamivir also are approved for treatment of influenza B. The costs, routes of administration, adverse effects, contraindications, approved ages, and potential for antiviral resistance differ among the four drugs. When administered within 48 hours of symptom onset, antiviral treatment of influenza can reduce the duration of illness by approximately 1 day in healthy adults (9). Data on the use of any of the four antiviral agents during pregnancy are not available. Amantadine, rimantadine, and oseltamivir also are approved for chemoprophylaxis of influenza A virus infections and can be used for control of institutional influenza outbreaks. When used for chemoprophylaxis, antivirals can be approximately $70 \%-90 \%$ effective in preventing illness in healthy adults $(9,10)$. To obtain information about approved age groups, dosing, and adverse effects, clinicians should consult antiviral drug package inserts (available from the Food and Drug Administration at http://www.fda.gov/cder/drug/antivirals/ influenza/default.htm\#drugs).

CDC has published recommendations for prevention and control of influenza (available at http://www.cdc.gov/mmwr/ $\mathrm{PDF} / \mathrm{rr} / \mathrm{rr}$ 5208.pdf). Supplemental recommendations have been released for the 2003-04 influenza season (Box). Influenza surveillance reports for the United States are published weekly during October-May and are available from CDC at http://www.cdc.gov/flu or through CDC's voice (telephone, 888-232-3228) and fax (telephone, 888-232-3299, document number 361100) information systems.

\section{Acknowledgments}

This report is based on data contributed by A Tulu, K Hankins, Dallas County Health and Human Svcs Office; G Wendell, 
o.rig.i.nal: adj

(ə-'rij-ən- ${ }^{\circ}$ ) 1 : being the first instance or source from which a copy, reproduction, or translation can be made; see also $M M W R$.

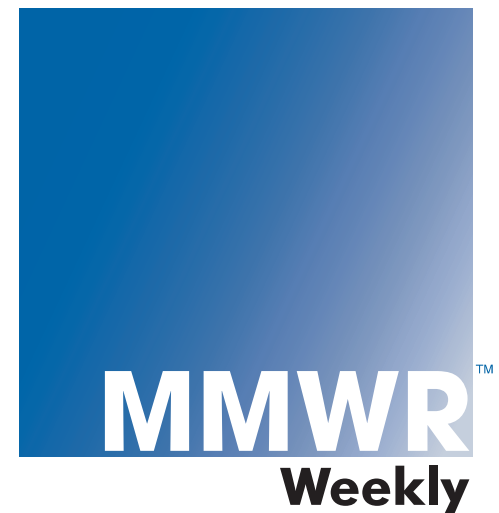




\section{BOX. CDC recommendations to prevent influenza}

\section{Vaccination}

- Emphasis should be placed on targeting trivalent inactivated vaccine to persons at high risk for complications from influenza: healthy children aged 6-23 months, adults aged $\geq 65$ years, pregnant women in their second or third trimester during influenza season, and persons aged $\geq 2$ years with underlying chronic conditions.

- Persons at high risk should be encouraged to search locally for vaccine if their usual health-care provider no longer has vaccine available.

- All children at high risk, including those aged 6-23 months, who report for vaccination should be vaccinated with a first or second dose, depending on vaccination status. Doses should not be held in reserve to ensure that two doses will be available.

- Next priority should be given to vaccinating those persons at greatest risk for transmission of disease to persons at high risk, including household contacts and health-care workers.

- Healthy persons aged 5-49 years should be encouraged to be vaccinated with intranasally administered live, attenuated influenza vaccine.

- Decisions about vaccinating healthy persons, including adults aged 50-64 years, with inactivated influenza vaccine should be made on a case-by-case basis, depending on local disease activity, vaccine coverage, feasibility, and supply.

- Health departments should work with their health-care providers to reallocate influenza vaccine to health-care providers in need when possible.

\section{Hygiene}

- Good respiratory hygiene should be encouraged, including cleaning of hands, and staying at home when symptomatic with fever and respiratory illness.

\section{Medication}

- Antiviral medications with specific activity against influenza A viruses should be considered either for treatment or chemoprophylaxis for influenza A, especially in persons at high risk for complications from influenza.

J Sheffield, Parkland Memorial Hospital, Dallas; J Siegel, Children's Medical Center, Dallas; N Pascoe, S Avashia, Texas Dept of Health. K Gershman, Colorado State Dept of Public Health and Environment. Participating state and territorial epidemiologists and state public health laboratory directors. WHO collaborating laboratories. National Respiratory and Enteric Virus Surveillance System collaborating laboratories, U.S. Influenza Sentinel Provider Surveillance System. Div of Public Health Surveillance and Informatics, Epidemiology Program Office; DJ O'Mara, Immunization Svcs Div, National Immunization Program, CDC.

\section{References}

1. CDC. Update: influenza activity-United States and worldwide, 200203 season, and composition of the 2003-04 influenza vaccine. MMWR 2003;52:516-21.

2. CDC. Surveillance for influenza-United States 1997-98, 1998-99, and 1999-00 seasons. In: CDC Surveillance Summaries (October 25). MMWR 2002;51(No. SS-7).

3. Thompson WW, Shay DK, Weintraub E, et al. Mortality associated with influenza and respiratory syncytial virus in the United States. JAMA 2003;289:179-86.

4. CDC. Severe morbidity and mortality associated with influenza in children and young adults-Michigan, 2003. MMWR 2003;52:837-40.

5. Morishima T, Togashi T, Yokata S, et al. Encephalitis and encephalopathy associated with an influenza epidemic in Japan. Clin Infect Dis 2002;35:512-7.

6. Mandell LA, Bartlett JG, Dowell SF, File TM, Musher DM, Whitney C. Update of practice guidelines for the management of communityacquired pneumonia in immunocompetent adults. Clin Infect Dis 2003;37:1405-33.

7. Johnston BL. Methicillin-resistant Staphylococcus aureus as a cause of community-acquired pneumonia-a critical review. Semin Respir Infect 1994;9:199-206.

8. CDC. Prevention and control of influenza: recommendations of the Advisory Committee on Immunization Practices (ACIP). MMWR 2003;52(No. RR-8).

9. Demicheli V, Jefferson T, Rivetti, Deeks J. Prevention and early treatment of influenza in healthy adults. Vaccine 2000;18:957-1030.

10. Hayden FG, Atmar RL, Schilling M, et al. Use of the selective oral neuraminidase inhibitor oseltamivir to prevent influenza. $\mathrm{N}$ Engl J Med 1999;341:1336-43.

\section{Revised U.S. Surveillance Case Definition for Severe Acute Respiratory Syndrome (SARS) and Update on SARS Cases - United States and Worldwide, December 2003}

During the 2003 epidemic of severe acute respiratory syndrome (SARS), CDC and the Council of State and Territorial Epidemiologists (CSTE) developed surveillance criteria to identify persons with SARS. The surveillance case definition changed throughout the epidemic as understanding of the clinical, laboratory, and transmission characteristics of SARSassociated coronavirus (SARS-CoV) increased (1-5). On June 26, CSTE adopted a position statement to add SARS-CoV disease to the National Notifiable Disease Surveillance System (NNDSS). The position statement included criteria for defining a SARS case for national reporting. On November 3, CSTE issued a new interim position statement* with a revised SARS case definition. This report summarizes the new

\footnotetext{
*The interim position statement must be ratified by the entire membership at the 2004 annual CSTE meeting. The statement is available from CSTE at http:// www.cste.org/ps/2003pdfs/2003finalpdf/cstesarscasedefrevision2003-10-30.pdf.
} 
U.S. surveillance case definition for SARS and updates reported cases of SARS worldwide and in the United States.

\section{Summary of Changes to Case Definition}

The revised SARS case definition (Box) modifies the clinical, epidemiologic, laboratory, and case-exclusion criteria in the U.S. surveillance case definition used during the 2003 epidemic. In the clinical criteria, "early" illness replaces "asymptomatic" or "mild" illness. The epidemiologic criteria include the following new categories: 1) possible exposure to SARS-CoV and 2) likely exposure to SARS-CoV. Laboratory criteria for evidence of SARS-CoV infection reflect advances in testing technology. The case-exclusion criteria have been changed to allow for exclusion when a serum sample collected $>28$ days after onset of symptoms is negative for antibody to SARS-CoV.

The revised case definition also classifies each SARS case as either a SARS report under investigation (SARS RUI) or SARS-CoV disease. SARS RUI is a sensitive, nonspecific case classification based solely on clinical or epidemiologic criteria and includes cases classified previously as probable or suspect. SARS-CoV disease is a more specific case classification based on selected clinical and epidemiologic criteria or laboratory confirmation. SARS RUIs might subsequently meet the definition for SARS-CoV disease based on results from laboratory testing (Tables 1 and 2).

\section{Update on SARS Cases}

During November 2002-July 2003, a total of 8,098 probable SARS cases were reported to the World Health Organization (WHO) from 29 countries, including 29 cases from the United States; 774 SARS-related deaths (case-fatality rate: 9.6\%) were reported, none of which occurred in the United States (6). Eight U.S. cases had serologic evidence of SARS$\mathrm{CoV}$ infection; these eight cases have been described previously (7-10). A total of 156 reported U.S. SARS cases from the 2003 epidemic remain under investigation, with 137 $(88 \%)$ cases classified according to previous surveillance criteria as suspect SARS and 19 (12\%) classified as probable SARS. Because convalescent serum specimens have not been obtained from the 19 probable and 137 suspect cases that remain under investigation, whether these persons had SARS$\mathrm{CoV}$ disease is unknown.

Reported by: SARS Team and Executive Committee, Council of State and Territorial Epidemiologists. SARS Investigative Team, CDC.

Editorial Note: The revised surveillance case definition for SARS reflects an improved understanding of the clinical and laboratory characteristics of SARS-CoV. The revision differentiates patients with nonspecific clinical illness or less defini- tive epidemiologic associations (i.e., SARS RUIs) from those with laboratory-confirmed SARS-CoV infection or more definitive epidemiologic links (i.e., cases of SARS-CoV disease). Local and state health departments will monitor SARS RUIs to ensure implementation of prompt public health measures for preventing disease transmission if SARS-CoV is confirmed subsequently. Numerous SARS RUIs probably will be excluded as SARS cases as laboratory results become available during the course of illness. Surveillance data for cases meeting the SARS-CoV disease case definition will be reported to NNDSS and included in the weekly statistical summary of notifiable infectious diseases in the United States published in MMWR (Table 1. Summary of provisional cases of selected notifiable diseases, United States).

Reporting of cases meeting previous SARS definitions ended in late July 2003. However, case numbers continue to change as new clinical information or results of additional laboratory testing on cases reported previously become available. Updated case counts reflecting these changes are available from CDC at http://www.cdc.gov/od/oc/media/sars/cases.htm.

Efforts are under way to prepare for a possible reappearance of SARS-CoV. CDC, in collaboration with other federal partners, state and local health officials, professional organizations and societies, and representatives of the health-care industry, has developed a guidance document to help public health and health-care officials detect the reappearance of SARS-CoV in the United States quickly and implement a decisive and effective public health response. The document, "Public Health Guidance for Community-Level Preparedness and Response to Severe Acute Respiratory Syndrome (SARS)," is available at http://www.cdc.gov/ncidod/sars/sarsprepplan.htm.

\section{References}

1. CDC. Outbreak of severe acute respiratory syndrome-worldwide, 2003. MMWR 2003;52:226-8.

2. CDC. Updated interim surveillance case definition for severe acute respiratory syndrome (SARS)—United States, April 29, 2003. MMWR 2003;52:391-3.

3. CDC. Update: severe acute respiratory syndrome-United States, May 21, 2003. MMWR 2003;52:466-8.

4. CDC. Update: severe acute respiratory syndrome-United States, June 4, 2003. MMWR 2003;52:525-6.

5. CDC. Update: severe acute respiratory syndrome-worldwide and United States, 2003. MMWR 2003;52:664-5.

6. World Health Organization. Summary table of SARS cases by country, November 1, 2002-August 7, 2003. Available at http://www.who. int/csr/sars/country/2003_08_15/en/.

7. CDC. Severe acute respiratory syndrome (SARS) and coronavirus testing-United States, 2003. MMWR 2003;52:297-302.

8. CDC. Update: severe acute respiratory syndrome-United States, 2003. MMWR 2003;52:357-60.

9. CDC. Update: severe acute respiratory syndrome-United States, May 28, 2003. MMWR 2003;52:500-1.

10. CDC. Update: severe acute respiratory syndrome-United States, June 11, 2003. MMWR 2003;52:550. 
BOX. Revised Council of State and Territorial Epidemiologists surveillance case definition for severe acute respiratory syndrome (SARS), December 2003

\section{Clinical Criteria}

Early illness

- Presence of two or more of the following features: fever (might be subjective), chills, rigors, myalgia, headache, diarrhea, sore throat, or rhinorrhea

Mild-to-moderate respiratory illness

- Temperature of $>100.4^{\circ} \mathrm{F}\left(>38^{\circ} \mathrm{C}\right)^{*}$ and

- One or more clinical findings of lower respiratory illness (e.g., cough, shortness of breath, or difficulty breathing)

Severe respiratory illness

- Meets clinical criteria of mild-to-moderate respiratory illness and

- One or more of the following findings:

- Radiographic evidence of pneumonia, or

- Acute respiratory distress syndrome, or

- Autopsy findings consistent with pneumonia or acute respiratory distress syndrome without an identifiable cause

\section{Epidemiologic Criteria}

Possible exposure to SARS-associated coronavirus (SARS-CoV)

One or more of the following exposures in the 10 days before onset of symptoms:

- Travel to a foreign or domestic location with documented or suspected recent transmission of SARS-CoV ${ }^{\dagger}$ or

- Close contact ${ }^{\S}$ with a person with mild-to-moderate or severe respiratory illness and history of travel in the 10 days before onset of symptoms to a foreign or domestic location with documented or suspected recent transmission of SARS-CoV ${ }^{\dagger}$

Likely exposure to SARS-CoV

One or more of the following exposures in the 10 days before onset of symptoms:

- Close contact ${ }^{\S}$ with a person with confirmed SARS-CoV disease or

- Close contact ${ }^{\S}$ with a person with mild-to-moderate or severe respiratory illness for whom a chain of transmission can be linked to a confirmed case of SARS-CoV disease in the 10 days before onset of symptoms

\section{Laboratory Criteria}

Tests to detect SARS-CoV are being refined and their performance characteristics assessed ${ }^{\boldsymbol{5}}$; therefore, criteria for laboratory diagnosis of SARS-CoV are changing. The following are general criteria for laboratory confirmation of SARS-CoV:

- Detection of serum antibody to SARS-CoV by a test validated by CDC (e.g., enzyme immunoassay), or

- Isolation in cell culture of SARS-CoV from a clinical specimen, or

- Detection of SARS-CoV RNA by a reverse transcription polymerase chain reaction test validated by CDC and with subsequent confirmation in a reference laboratory (e.g., CDC).

Information about the current criteria for laboratory diagnosis of SARS-CoV is available at http://www.cdc.gov/ncidod/ sars/labdiagnosis.htm.

\section{Exclusion Criteria}

A case may be excluded as a SARS report under investigation (SARS RUI), including as a CDC-defined probable SARSCoV case, if any of the following apply:

- An alternative diagnosis can explain the illness fully**, or

- Antibody to SARS-CoV is undetectable in a serum specimen obtained $>28$ days after onset of illness ${ }^{\dagger \dagger}$, or

- The case was reported on the basis of contact with a person who was excluded subsequently as a case of SARS-CoV disease; then the reported case also is excluded, provided other epidemiologic or laboratory criteria are not present.

\section{Case Classification}

SARS RUI

Reports in persons from areas where SARS is not known to be active

- SARS RUI-1: Cases compatible with SARS in groups likely to be first affected by SARS-CoV $\$ \mathbb{S}$ if SARS-CoV is introduced from a person without clear epidemiologic links to known cases of SARS-CoV disease or places with known ongoing transmission of SARS-CoV 
BOX. (Continued) Revised Council of State and Territorial Epidemiologists surveillance case definition for severe acute respiratory syndrome (SARS), December 2003

Reports in persons from areas where SARS activity is occurring

- SARS RUI-2: Cases meeting the clinical criteria for mild-to-moderate illness and the epidemiologic criteria for possible exposure (spring 2003 CDC definition for suspect cases ${ }^{\mathbf{9 9}}$ )

- SARS RUI-3: Cases meeting the clinical criteria for severe illness and the epidemiologic criteria for possible exposure (spring 2003 CDC definition for probable cases 9 )

- SARS RUI-4: Cases meeting the clinical criteria for early or mild-to-moderate illness and the epidemiologic criteria for likely exposure to SARS-CoV

SARS-CoV disease

- Probable case of SARS-CoV disease: meets the clinical criteria for severe respiratory illness and the epidemiologic criteria for likely exposure to SARS-CoV

- Confirmed case of SARS-CoV disease: clinically compatible illness (i.e., early, mild-to-moderate, or severe) that is laboratory confirmed

* A measured documented temperature of $>100.4^{\circ} \mathrm{F}\left(>38^{\circ} \mathrm{C}\right)$ is expected. However, clinical judgment may allow a small proportion of patients without a documented fever to meet this criterion. Factors that might be considered include patient's self-report of fever, use of antipyretics, presence of immunocompromising conditions or therapies, lack of access to health care, or inability to obtain a measured temperature. Initial case classification based on reported information might change, and reclassification might be required.

$\dagger$ Types of locations specified will vary (e.g., country, airport, city, building, or floor of building). The last date a location may be a criterion for exposure is 10 days (one incubation period) after removal of that location from CDC travel alert status. The patient's travel should have occurred on or before the last date the travel alert was in place. Transit through a foreign airport meets the epidemiologic criteria for possible exposure in a location for which a CDC travel advisory is in effect. Information about CDC travel alerts and advisories and assistance in determining appropriate dates are available at http://www.cdc.gov/ncidod/sars/ travel.htm.

$\$$ Close contact is defined as having cared for or lived with a person with SARS or having a high likelihood of direct contact with respiratory secretions and/or body fluids of a person with SARS (during encounters with the patient or through contact with materials contaminated by the patient) either during the period the person was clinically ill or within 10 days of resolution of symptoms. Examples of close contact include kissing or embracing, sharing eating or drinking utensils, close (i.e., $<3$ feet) conversation, physical examination, and any other direct physical contact between persons. Close contact does not include activities such as walking by a person or sitting across a waiting room or office for a brief time.

The identification of the etiologic agent of SARS (i.e., SARS-CoV) led to the rapid development of enzyme immunoassays and immunofluorescence assays for serologic diagnosis and reverse transcription polymerase chain reaction assays for detection of SARS-CoV RNA in clinical samples. These assays can be very sensitive and specific for detecting antibody and RNA, respectively, in the later stages of SARS-CoV disease. However, both are less sensitive for detecting infection early in illness. The majority of patients in the early stages of SARS-CoV disease have a low titer of virus in respiratory and other secretions and require time to mount an antibody response. SARS-CoV antibody tests might be positive as early as 8-10 days after onset of illness and often by 14 days after onset of illness, but sometimes not until 28 days after onset of illness. Information about the current criteria for laboratory diagnosis of SARS-CoV is available at http://www.cdc.gov/ncidod/sars/ labdiagnosis.htm.

** Factors that may be considered in assigning alternate diagnoses include the strength of the epidemiologic exposure criteria for SARS-CoV disease, the specificity of the alternate diagnostic test, and the compatibility of the clinical presentation and course of illness with the alternative diagnosis.

i† Current data indicate that $>95 \%$ of patients with SARS-CoV disease mount an antibody response to SARS-CoV. However, health officials may choose not to exclude a case on the basis of lack of a serologic response if reasonable concern exists that an antibody response could not be mounted.

$\$ \mathbb{S}$ Consensus guidance is in development between CDC and CSTE on which groups are most likely to be affected first by SARS-CoV if it reemerges. SARS-CoV disease should be considered at a minimum in the differential diagnoses for persons requiring hospitalization for pneumonia confirmed radiographically or acute respiratory distress syndrome without identifiable etiology and who have one of the following risk factors in the 10 days before the onset of illness:

- Travel to mainland China, Hong Kong, or Taiwan, or close contact with an ill person with a history of recent travel to one of these areas, or

- Employment in an occupation associated with a risk for SARS-CoV exposure (e.g., health-care worker with direct patient contact or worker in a laboratory that contains live SARS-CoV), or

- Part of a cluster of cases of atypical pneumonia without an alternative diagnosis.

Guidelines for the identification, evaluation, and management of these patients are available at http://www.cdc.gov/ncidod/sars/absenceofsars.htm.

99 During the 2003 SARS epidemic, CDC case definitions were the following:

Suspect case

- Meets the clinical criteria for mild-to-moderate respiratory illness and the epidemiologic criteria for possible exposure to SARS-CoV but does not meet any of the laboratory criteria and exclusion criteria or

- Unexplained acute respiratory illness that results in death of a person on whom an autopsy was not performed and that meets the epidemiologic criteria for possible exposure to SARS-CoV but does not meet any of the laboratory criteria and exclusion criteria

Probable case

- Meets the clinical criteria for severe respiratory illness and the epidemiologic criteria for possible exposure to SARS-CoV but does not meet any of the laboratory criteria and exclusion criteria. 
TABLE 1. Severe acute respiratory syndrome-associated coronavirus (SARS-CoV) case classification before laboratory testing, by clinical and epidemiologic criteria

\begin{tabular}{lccc}
\hline \multirow{2}{*}{$\begin{array}{c}\text { Epidemiologic } \\
\text { criteria }\end{array}$} & \multicolumn{3}{c}{ Clinical criteria for degree of illness } \\
\cline { 2 - 4 } & Early & $\begin{array}{c}\text { Mild to } \\
\text { moderate }\end{array}$ & Severe \\
\hline Unknown & - & - & SARS RUI*-1 \\
Possible & - & SARS RUI-2 & SARS RUI-3 \\
Likely & SARS RUI-4 & SARS RUI-4 & $\begin{array}{l}\text { Probable case of } \\
\text { SARS-CoV disease }\end{array}$ \\
\hline
\end{tabular}

${ }^{*}$ Report under investigation.

TABLE 2. Severe acute respiratory syndrome-associated coronavirus (SARS-CoV) case classification after laboratory testing, by initial report category

\begin{tabular}{|c|c|c|c|}
\hline \multirow{2}{*}{$\begin{array}{l}\text { Initial report } \\
\text { category }\end{array}$} & \multicolumn{3}{|c|}{ Laboratory testing results } \\
\hline & Negative* $^{*}$ & Positive & Not performed \\
\hline $\begin{array}{l}\text { SARS RUI }{ }^{\dagger}-1 \\
\text { to SARS RUI-4 }\end{array}$ & Excluded & $\begin{array}{l}\text { Confirmed case of } \\
\text { SARS-CoV disease }\end{array}$ & Undetermined $\S$ \\
\hline $\begin{array}{l}\text { Probable case } \\
\text { of SARS-CoV } \\
\text { disease }\end{array}$ & Excluded & $\begin{array}{l}\text { Confirmed case of } \\
\text { SARS-CoV disease }\end{array}$ & $\begin{array}{l}\text { Probable case of } \\
\text { SARS-CoV disease }\end{array}$ \\
\hline
\end{tabular}

${ }^{*}$ Negative test as defined by negative antibody titer taken $>28$ days after the onset of symptoms. A negative polymerase chain reaction result does not rule out SARS-CoV disease.

†eport under investigation.

${ }^{\S}$ Collection and/or laboratory testing of specimen was not completed.

\section{Reptile-Associated Salmonellosis - Selected States, 1998-2002}

During 1998-2002, CDC received reports from state health departments regarding Salmonella infections in persons who had contact with reptiles (e.g., lizards, snakes, and turtles). Salmonella infections usually cause gastroenteritis but can result in invasive illness (e.g., septicemia and meningitis), especially in infants and immunocompromised persons. For decades, reptiles have been known as a source for salmonellosis (1); however, numerous reptile owners remain unaware that reptile contact places them and other household members, including children, at greater risk for salmonellosis (2). Increasing evidence suggests that amphibians (e.g., frogs, toads, newts, and salamanders) also can pose risks for salmonellosis in humans $(3,4)$. This report describes cases of reptile-associated salmonellosis in six states*, offers recommendations on preventing transmission of Salmonella from reptiles and amphibians to humans (Box), and provides an update on state regulations mandating education at pet stores about salmonellosis.

\footnotetext{
*California, Connecticut, Florida, North Dakota, Ohio, and Wisconsin. At least six other states (Kansas, Maine, Maryland, Oklahoma, Washington, and Wyoming) reported similar cases.
}

BOX. Recommendations for preventing transmission of Salmonella from reptiles and amphibians to humans

- Pet-store owners, health-care providers, and veterinarians should provide information to owners and potential purchasers of reptiles and amphibians about the risks for and prevention of salmonellosis from these pets.

- Persons at increased risk for infection or serious complications from salmonellosis (e.g., children aged $<5$ years and immunocompromised persons) should avoid contact with reptiles and amphibians and any items that have been in contact with reptiles and amphibians.

- Reptiles and amphibians should be kept out of households that include children aged $<5$ years or immunocompromised persons. A family expecting a child should remove any pet reptile or amphibian from the home before the infant arrives.

- Reptiles and amphibians should not be allowed in childcare centers.

- Persons always should wash their hands thoroughly with soap and water after handling reptiles and amphibians or their cages.

- Reptiles and amphibians should not be allowed to roam freely throughout a home or living area.

- Pet reptiles and amphibians should be kept out of kitchens and other food-preparation areas. Kitchen sinks should not be used to bathe reptiles and amphibians or to wash their dishes, cages, or aquariums. If bathtubs are used for these purposes, they should be cleaned thoroughly and disinfected with bleach.

- Reptiles and amphibians in public settings (e.g., zoos and exhibits) should be kept from direct or indirect contact with patrons except in designated animal-contact areas equipped with adequate hand-washing facilities. Food and drink should not be allowed in animalcontact areas.

\section{Case Reports}

California. During December 2001, an infant aged 3 months was taken to an emergency department (ED) after 1 day of bloody diarrhea and fever. The infant was sent home with no therapy and recovered in 2 days; a stool specimen yielded Salmonella serotype Nima. Although no reptiles lived in the home, the infant's father was a high school biology teacher who handled reptiles in the classroom, including a large snake (i.e., a boa) that he often draped over his shoulders. A stool culture from the snake grew $S$. Nima. When interviewed, the father indicated that he knew reptiles carry Salmonella and was careful to wash his hands after handling them or their containers. However, he did not change clothing when he came home from work before holding his child. 
Connecticut. During June 2002, a child aged 21 months was admitted to a hospital with fever, abdominal cramps, and bloody diarrhea. The child received no antibiotic therapy and was discharged the next day. Blood and stool cultures yielded Salmonella serotype Poona. A sibling aged 6 years also had fever and bloody diarrhea and a stool culture that yielded $S$. Poona. The family had purchased an iguana approximately 1 month earlier. The children had cleaned the iguana's cage and handled the iguana 2 days before their illness onsets. A stool culture from the iguana grew $S$. Poona; isolates from the iguana and the two siblings were indistinguishable by pulsedfield gel electrophoresis (PFGE).

Florida. During January 2000, an infant aged 1 month visited a clinic with fever and diarrhea; the infant was not hospitalized. A stool specimen yielded Salmonella serotype Tennessee. One week before illness onset, the infant's family moved into a household that contained a bearded dragon (i.e., Pogona vitticeps). The pet reptile's cage had been washed in the kitchen near the infant's bottle nipples. A stool culture from the bearded dragon yielded $S$. Tennessee. Isolates from the infant and the bearded dragon were indistinguishable by PFGE. An adult in the house reported being aware that turtles and iguanas are reservoirs for Salmonella but unaware that all reptiles can carry Salmonella. The bearded dragon was placed outside the home and later donated to a zoo.

North Dakota. During March 1998, twin infants aged 2 weeks were admitted to a hospital after 1 day of poor feeding, diarrhea, and fever. They were treated intravenously with ampicillin for 6 days. The infants' mother and a child aged 3 years in the home also had diarrhea. Stool specimens from one of the twins, the mother, and the older child yielded Salmonella with the partial serotype $\mathrm{O}$ group $44,45,47,48$, or $50, \mathrm{H}$ antigen $\mathrm{G}$ complex. The family recently had acquired an iguana, which was not allowed out of its cage. Only the mother handled the reptile and cleaned the cage. When the family learned that the iguana was the probable source of Salmonella infections, the iguana was euthanized. Culture of intestinal contents from the iguana yielded Salmonella with the same partial serotype as the patients' isolates. The clinical isolate from the twin was sent to CDC for complete serotyping and found to be Salmonella serotype IV 48:g, $\mathrm{z}_{51}$ :- (known formerly as $S$. Marina).

Ohio. During August-October 2000, local health departments reported seven gastrointestinal illnesses associated with iguanas or turtles acquired at county fairs. In one incident, two siblings aged 11 and 13 years with diarrhea and abdominal cramping visited an ED. No stool specimens were collected from the children. However, stool specimens from a turtle that the siblings received at a county fair yielded Salmonella serotype Sandiego. During the same period, a stool speci- men from a man aged 20 years with diarrhea also yielded $S$. Sandiego; he recently had won a turtle at a county fair. Isolates from the children's turtle and the man were indistinguishable by PFGE.

Wisconsin. During November 2002, an infant aged 24 days was admitted to a hospital after 1 day of bloody diarrhea. The infant was hospitalized for 3 days and received intravenous fluids and supportive care. A stool culture yielded Salmonella

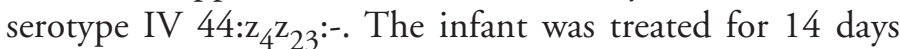
with oral amoxicillin. An iguana was reported living in the home of the infant's father; however, attempts to collect stool samples from the iguana were unsuccessful.

Two weeks later, an infant aged 4 months in a neighboring county visited a hospital after 8 days of fever of $100.3^{\circ} \mathrm{F}$ $\left(37.9^{\circ} \mathrm{C}\right)$ and 3 days of decreased range of motion in the left hip. Salmonella serotype IV $44: \mathrm{z}_{4} \mathrm{z}_{23}$ :- was isolated from both left hip aspirate and blood cultures. The infant was hospitalized for 6 days and treated intravenously with cefotaxime and gentamicin. An iguana was reported living in the infant's home, but the reptile was removed before it could be tested. Both iguanas associated with the infants were traced back by the state health department to the same distributor in Florida.

Reported by: $R$ Reporter, MD, Los Angeles County Health Dept; B Sun, DVM, California Dept of Health Svcs. J Monopoli, MPH, East Shore Health District, Branford; Q Phan, MPH, J Hadler, MD, Connecticut Dept of Public Health. P Tiffany, Osceola County Health Dept; Z Mulla, PhD, R Baker, MS, PD Fiorella, PhD, Florida Dept of Health. K Kruger, L Shireley, MPH, D Johnson, MS, D Steinbach, North Dakota Dept of Health. KSmith, DVM, E Salehi, MPH, Ohio Dept of Health. N Joseph, J Archer, MS, J Davis, MD, Wisconsin Dept of Health and Family Svcs. N Snipes, DVM, J Ovitt, DVM, F Angulo, DVM, Div of Bacterial and Mycotic Diseases, National Center for Infectious Diseases; S Gottlieb, MD, EIS Officer, CDC.

Editorial Note: Salmonellosis associated with reptiles is a continuing public health concern $(5,6)$. During the 1970s, small pet turtles were a major source of Salmonella infections in the United States (1). In 1975, the Food and Drug Administration banned commercial distribution of small (i.e., $<4$ in. long) turtles; the majority of states prohibited the sale of such turtles. These measures prevented an estimated 100,000 cases of salmonellosis among children each year (1). However, reptiles remain popular pets in the United States; during 1991-2001, the estimated number of households with reptiles doubled from approximately 850,000 to 1.7 million (7). The increase in pet reptile popularity has been paralleled by an increase in the number of reptile-related Salmonella serotypes isolated from humans $(2,6)$.

Reptiles are commonly colonized with Salmonella and shed the organism intermittently in their feces (G). Attempts to treat reptiles with antibiotics to eliminate Salmonella carriage 


\section{"The important thing is not to stop questioning."}

\author{
Albert Einstein
}

\begin{abstract}
Medicine is constantly changingtoday's answers often become tomorrow's questions. That's where MMWR Continuing Education can help.
\end{abstract}

With timely courses on public health and clinical topics, our online program makes it easy for you to stay current. Take exams, track results, and receive course certificates - when and where your schedule allows.

MMWR CE

Important questions. And answers.

cdc.gov/mmwr

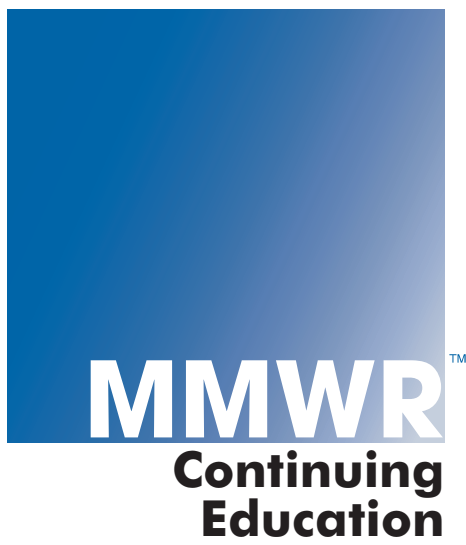

have been unsuccessful and might lead to increased antibiotic resistance (5). Salmonella survives well in the environment and can be isolated for prolonged periods from surfaces contaminated by reptile feces $(8)$. For this reason, even minimal indirect contact with reptiles can result in illness $(2,5)$.

Increasing evidence suggests that amphibians also are a source for salmonellosis $(3,4)$. Frogs and toads are frequent carriers of Salmonella and have been linked by epidemiologic evidence to outbreaks $(3,4)$. In a population-based, casecontrol study, housing an amphibian was associated independently with Salmonella infection (3). Overall, reptile and amphibian contacts are estimated to account for 74,000 (6\%) of the approximately 1.2 million sporadic Salmonella infections that occur each year in the United States (3).

Gaps remain in the public's understanding of amphibianand reptile-associated salmonellosis. In one study, fewer than half the families with salmonellosis and known iguana exposure suspected their iguanas might have been the cause of illness (2). Pet-store owners, health-care providers, and veterinarians should provide information and prevention messages about salmonellosis to owners and potential purchasers of reptiles and amphibians. Educational materials are available from the Pet Industry Joint Advisory Council, telephone 800-553-7387.

In 1999, the National Association of State Public Health Veterinarians and the Council of State and Territorial Epidemiologists recommended that state and local agencies adopt regulations to prohibit the sale or gift of reptiles without written point-of-sale education to consumers about the risks for and prevention of reptile-associated salmonellosis (9). In February 2003, CDC polled health departments in all 50 states and New York City (NYC) to determine whether such regulations existed. Among the 49 health departments responding, four states (Colorado, Illinois, Kansas, and Texas) required pet stores to provide information about salmonellosis to persons purchasing any reptile; five (California, Connecticut, Maryland, Michigan, and New York) required providing salmonellosis information to persons purchasing a turtle but not other reptiles. Tennessee prohibited sale of all turtles. NYC prohibited sale of certain reptiles, including iguanas, small turtles, and boas, and required posting of information about reptile-associated salmonellosis where other reptiles were sold.

Evaluation of the effectiveness of mandated point-of-sale education in reducing amphibian- and reptile-associated salmonellosis could help guide future prevention efforts. In the meantime, areas such as NYC have adopted restrictions on the sale of certain reptiles similar to those for small turtles. 


\section{References}

1. Cohen ML, Potter M, Pollard R, Feldman RA. Turtle-associated salmonellosis in the United States: effect of public health action, 1970 to 1976. JAMA 1980;243:1247-9.

2. Mermin J, Hoar B, Angulo FJ. Iguanas and Salmonella Marina infection in children: a reflection of the increasing incidence of reptileassociated salmonellosis in the United States. Pediatrics 1997;99: 399-402.

3. Mermin J, Hutwagner L, Vugia D, et al. Reptiles, amphibians, and human Salmonella infection: a population-based, case-control study. Clin Infect Dis Suppl (in press).

4. Srikantiah P, Lay JC, Crump JA, et al. An outbreak of Salmonella Javiana associated with amphibian contact-Mississippi, 2001. Presented at the International Conference on Emerging Infectious Diseases, Atlanta, Georgia, 2002.

5. CDC. Reptile-associated salmonellosis_-selected states, 1994-1995. MMWR 1995;44:347-50.

6. CDC. Reptile-associated salmonellosis-selected states, 1996-1998. MMWR 1999;48:1009-13.

7. Wise JK, Heathcott BL, Gonzalez ML. Results of the AVMA survey on companion animal ownership in U.S. pet-owning households. J Am Vet Med Assoc 2002;221:1572-3.

8. Friedman CR, Torigian C, Shillam PJ, et al. An outbreak of salmonellosis among children attending a reptile exhibit at a zoo. J Pediatr 1998; 132:802-7.

9. Council of State and Territorial Epidemiologists. Reptile-associated salmonellosis and prevention education. CSTE position statement 1999ID 13. Available at http://www.cste.org/ps/1999/1999-id-13.htm.

\section{Public Health Dispatch}

\section{Tuberculosis Outbreak Among Homeless Persons - King County, Washington, 2002-2003}

The Public Health-Seattle and King County (PH-SKC) Tuberculosis Control Program, with assistance from the Washington State Department of Health and CDC, is continuing to investigate an ongoing outbreak of tuberculosis (TB) disease among homeless persons in Seattle (1). This report describes patient characteristics, methods used to identify active TB cases and contacts at highest risk for exposure, and control measures under way to prevent further transmission of this outbreak strain of Mycobacterium tuberculosis.

During 1999-2001, PH-SKC reported an annual average of 13 cases of TB among the homeless population. In 2002, diagnosis of TB in 30 homeless patients prompted an investigation. As of September 30, 2003, PH-SKC had identified 44 outbreak-associated TB patients with dates of diagnosis during May 2002-September 2003. Outbreak-associated TB patients have been defined according to the following criteria: 1) having an $M$. tuberculosis isolate with a matching 15-band restriction fragment length polymorphism (RFLP) pattern (2) $(\mathrm{n}=39)$ or 2) if RFLP analysis is pending, having an epidemiologic link to a patient whose isolate matched the outbreak pattern $(\mathrm{n}=$ five). All but three of the outbreak-associated patients were homeless at the time of diagnosis; 43 (98\%) were born in the United States, 34 (77\%) were male, 21 (48\%) were American Indian/Alaska Native, and 17 (39\%) were black. Of the $38(86 \%)$ patients with pulmonary disease, 23 $(61 \%)$ had acid-fast bacilli identified on sputum smear at diagnosis. Seven (16\%) outbreak-associated patients also were infected with human immunodeficiency virus (HIV).

In January 2003, an investigation conducted by PH-SKC assisted in identifying contacts at highest risk for exposure. Investigators reinterviewed outbreak patients and health-care providers serving homeless facilities to identify additional patient contacts. Sites of transmission were determined by review of homeless facility intake registries for the presence of infectious patients and the rates of positive tuberculin skin testing (TST) results among staff and clients. Exposed cohorts were identified at three sites of transmission. The cohort prioritized for intensive screening included 385 contacts from three homeless facilities and 86 other contacts named by patients or health-care providers.

In February 2003, PH-SKC began an intensive effort to screen the high-priority cohort for TB disease and latent TB infection (LTBI) in the TB clinic and at homeless facilities, which included symptom review, chest radiograph, sputum examination and culture, TST, and voluntary HIV counseling and testing. During February 1-September 30, PH-SKC screened approximately 380 contacts with a chest radiograph and/or sputum culture. Of the 44 outbreak-associated patients, 20 were reported during this time, and 11 (55\%) were identified through PH-SKC screening efforts, limiting the amount of time these patients were exposing others in the community. As of December 9, all homeless outbreak-associated patients with TB disease and some contacts with LTBI were receiving directly observed therapy.

Focused, intensified screening efforts for early detection and treatment of both TB disease and LTBI are under way to control transmission in the King County community (3). TB controllers, particularly those from western states, should consider the possibility of unrecognized TB outbreaks involving homeless persons in their communities.

Reported by: M Narita, MD, S Goldberg, MD, L Lake, MBA, Public Health-Seattle and King County; T Kuss, MPH, K Field, MSN, J Hofmann, MD, Washington State Dept of Health. P McElroy, PhD, $P$ Tribble, MA, Div of Tuberculosis Elimination; B Metchock, DrPH, Div of AIDS, STD, and Tuberculosis Laboratory Research; M McConnell, MD, Global AIDS Program, National Center for HIV, STD, and Tuberculosis Prevention; K Lofy, MD, EIS Officer, CDC.

\section{References}

1. Public Health Seattle and King County. Recent increase in tuberculosis among homeless persons in King County. Epi-Log Communicable Disease and Epidemiology News 2002;42:11. Available at http://www. metrokc.gov/health/phnr/prot_res/epilog/vol4211.htm\#tb. 
2. van Embden JD, Cave MD, Crawford JT, et al. Strain identification of Mycobacterium tuberculosis by DNA fingerprinting: recommendations for a standardized methodology. J Clin Microbiol 1993;31:406-9.

3. CDC. Prevention and control of tuberculosis among homeless persons: recommendations of the Advisory Council for the Elimination of Tuberculosis. MMWR 1992;41(No. RR-5).

\section{Notice to Readers}

\section{Request for Information About Acute Encephalopathy Associated with Influenza Virus Infection in U.S. Children}

Since the mid-1990s, several hundred cases of acute encephalopathy have been reported in Japanese children with influenza virus infection $(1,2)$. These cases have been characterized by fever and rapid onset of encephalopathy, resulting in a high frequency of neurologic sequelae and mortality. The majority of the children have had laboratory-confirmed evidence of influenza.

Reports of influenza-associated encephalopathy have been uncommon in the United States $(3,4)$. To determine if a similar pattern is occurring in the United States, CDC is requesting information on any case meeting certain criteria. The criteria include a person aged $<18$ years with altered mental status or personality change lasting $>24$ hours and occurring within 5 days of onset of an acute febrile respiratory illness, laboratory or rapid diagnostic test evidence of acute influenza virus infection associated with the respiratory illness, and diagnosis of the condition in the United States. Cases meeting these criteria should be reported to CDC (telephone, 404-639-0277 or 404-639-2893; fax, 404-639-3866; or e-mail,tmu0@cdc.gov or nib9@cdc.gov).

\section{References}

1. Morishima T, Togashi T, Yokata S, et al. Encephalitis and encephalopathy associated with an influenza epidemic in Japan. Clin Infect Dis 2002;35:512-7.

2. Sugaya N. Influenza-associated encephalopathy in Japan. Semin Pediatr Infect Dis 2002;13:79-84.

3. McCullers JA, Facchini S, Chesney PJ, Webster RG. Influenza B virus encephalitis. Clin Infect Dis 1999;28:898-900.

4. Straumanis JP, Tapia MD, King JC. Influenza B infection associated with encephalitis: treatment with oseltamivir. Pediatr Infect Dis J $2002 ; 21: 173-5$

\section{Notice to Readers}

\section{Inclusion of Official Counts of SARS-CoV Disease in National Notifiable Diseases Surveillance System Data Presentation}

Beginning with this issue of $M M W R$, severe acute respiratory syndrome-associated coronavirus (SARS-CoV) disease incidence data are being added to Table I, Summary of provisional cases of selected notifiable diseases, United States. Effective July 1, 2003, SARS-CoV disease was added to the list of nationally notifiable conditions as designated by the Council of State and Territorial Epidemiologists and with concurrence from CDC (1). The National Notifiable Diseases Surveillance System (NNDSS) is the official source of SARS$\mathrm{CoV}$ disease case counts.

No SARS-CoV disease cases were reported in the United States from July 1, 2003 (27th week) through December 6, 2003 (49th week). However, as an aid to future data interpretation and comparison, SARS-CoV incidence data were included in NNDSS for the first half of the year (week ending January 4, 2003, [first week] through week ending June 28, 2003 [26th week]). Cumulative SARS-CoV disease incidence data for $M M W R$ weeks 1-49 (week ending December 6, 2003) are presented in Table I.

\section{Reference}

1. CDC. Revised U.S. surveillance case definition for severe acute respiratory syndrome (SARS) and update on SARS cases-United States and worldwide, December 2003. MMWR 2003;52:1202-6.

\section{Erratum: Vol. 52, No. 41}

In the report, "Infants Tested for Hearing Loss-United States, 1999-2001," an error occurred in the fourth paragraph on page 982. The paragraph should read, "For 1999, five states/ areas reported that 179 infants were identified with HL; 108 $(60.3 \%)$ were enrolled in early intervention programs by age 6 months. In 2001, a total of 24 states/areas reported that 1,306 infants were identified with HL; 831 (63.6\%) were enrolled in early intervention programs. Of these 831 enrolled infants, $579(69.7 \%)$ reportedly were enrolled by age 6 months." 
FIGURE I. Selected notifiable disease reports, United States, comparison of provisional 4-week totals December 6, 2003, with historical data

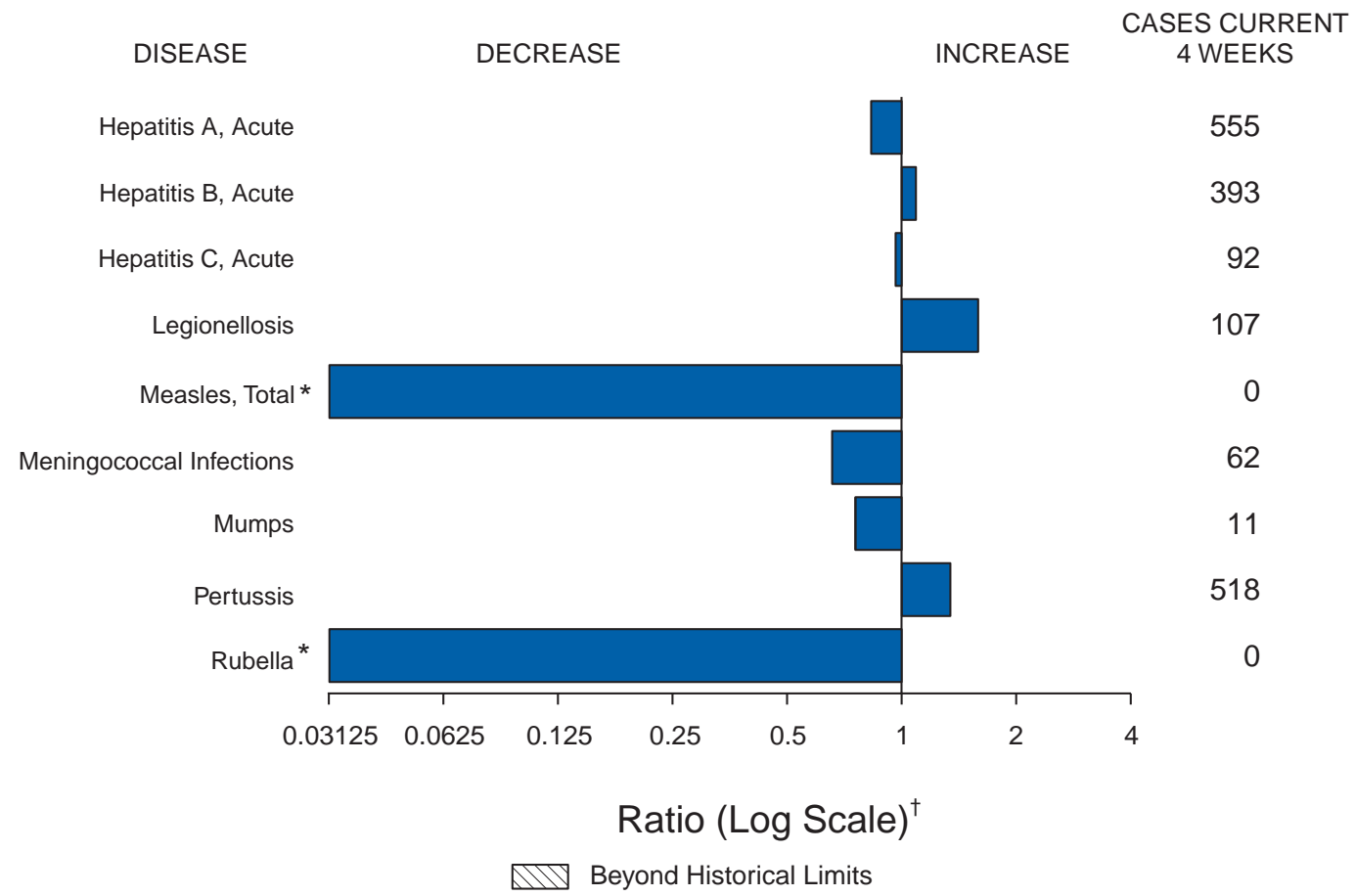

\footnotetext{
* No measles or rubella cases were reported for the current 4-week period yielding a ratio for week 49 of zero (0).

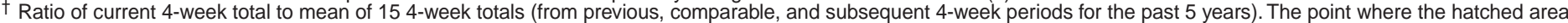
begins is based on the mean and two standard deviations of these 4-week totals.
}

TABLE I. Summary of provisional cases of selected notifiable diseases, United States, cumulative, week ending December 6, 2003 (49th Week)*

Anthrax

Botulism:

Chancroid

Cholera

Cyclosporiasis ${ }^{\dagger}$

Diphtheria

Ehrlichiosis:

human granulocytic $(\mathrm{HGE})^{\dagger}$ human monocytic $(\mathrm{HME})^{\dagger}$ other and unspecified

Encephalitis/Meningitis:

California serogroup viral eastern equine

Powassan $^{\dagger}$

St. Louis ${ }^{\dagger}$ western equine $^{\dagger}$

\begin{tabular}{|c|c|c|c|c|}
\hline $\begin{array}{l}\text { Cum. } \\
2003\end{array}$ & $\begin{array}{l}\text { Cum. } \\
2002\end{array}$ & & $\begin{array}{l}\text { Cum. } \\
2003\end{array}$ & $\begin{array}{l}\text { Cum. } \\
2002\end{array}$ \\
\hline- & 2 & Hansen disease (leprosy) ${ }^{\dagger}$ & 54 & 82 \\
\hline- & - & Hantavirus pulmonary syndrome ${ }^{\dagger}$ & 17 & 17 \\
\hline 17 & 26 & Hemolytic uremic syndrome, postdiarrheal ${ }^{\dagger}$ & 143 & 197 \\
\hline 60 & 64 & HIV infection, pediatric ${ }^{\dagger \S}$ & 204 & 152 \\
\hline 30 & 18 & Measles, total & $43^{\pi}$ & $39^{* *}$ \\
\hline 80 & 111 & Mumps & 183 & 248 \\
\hline 43 & 64 & Plague & 1 & 2 \\
\hline 1 & 2 & Poliomyelitis, paralytic & - & - \\
\hline 62 & 157 & Psittacosis $^{\dagger}$ & 14 & 16 \\
\hline 1 & 1 & $Q$ fever $^{\dagger}$ & 66 & 55 \\
\hline- & - & Rabies, human & 3 & 3 \\
\hline 332 & 312 & Rubella & 8 & 16 \\
\hline 192 & 192 & Rubella, congenital & - & 1 \\
\hline 41 & 22 & SARS-associated coronavirus disease ${ }^{\dagger \dagger}$ & 8 & NA \\
\hline- & - & Streptococcal toxic-shock syndrome ${ }^{\dagger}$ & 132 & 105 \\
\hline 83 & 144 & Tetanus & 13 & 22 \\
\hline 10 & 8 & Toxic-shock syndrome & 121 & 99 \\
\hline- & 1 & Trichinosis & 4 & 14 \\
\hline 36 & 20 & Tularemia $^{\dagger}$ & 76 & 72 \\
\hline 5 & - & Yellow fever & - & - \\
\hline
\end{tabular}

$-:$ No reported cases.

* Incidence data for reporting years 2002 and 2003 are provisional and cumulative (year-to-date).

Not notifiable in all states.

$\S$ Updated monthly from reports to the Division of HIV/AIDS Prevention — Surveillance and Epidemiology, National Center for HIV, STD, and TB Prevention.

Last update November 30, 2003.

I Of 43 cases reported, 32 were indigenous, and 11 were imported from another country.

** Of 39 cases reported, 24 were indigenous, and 15 were imported from another country.

t† Updated weekly from reports to the Division of Viral and Rickettsial Diseases, National Center for Infectious Diseases (notifiable as of July 2003). 
TABLE II. Provisional cases of selected notifiable diseases, United States, weeks ending December 6, 2003, and December 7, 2002 (49th Week)*

\begin{tabular}{|c|c|c|c|c|c|c|c|c|c|c|}
\hline \multirow[b]{2}{*}{ Reporting area } & \multicolumn{2}{|c|}{ AIDS } & \multicolumn{2}{|c|}{ Chlamydia $^{\dagger}$} & \multicolumn{2}{|c|}{ Coccidiodomycosis } & \multicolumn{2}{|c|}{ Cryptosporidiosis } & \multicolumn{2}{|c|}{$\begin{array}{c}\text { Encephalitis/Meningitis } \\
\text { West Nile }\end{array}$} \\
\hline & $\begin{array}{l}\text { Cum. } \\
2003^{\S}\end{array}$ & $\begin{array}{l}\text { Cum. } \\
2002\end{array}$ & $\begin{array}{l}\text { Cum. } \\
2003\end{array}$ & $\begin{array}{l}\text { Cum. } \\
2002\end{array}$ & $\begin{array}{l}\text { Cum. } \\
2003\end{array}$ & $\begin{array}{l}\text { Cum. } \\
2002\end{array}$ & $\begin{array}{l}\text { Cum. } \\
2003\end{array}$ & $\begin{array}{l}\text { Cum. } \\
2002\end{array}$ & $\begin{array}{l}\text { Cum. } \\
2003\end{array}$ & $\begin{array}{l}\text { Cum. } \\
2002\end{array}$ \\
\hline UNITED STATES & 41,832 & 38,707 & 771,602 & 780,541 & 3,993 & 3,834 & 3,111 & 2,833 & 1,785 & 2,621 \\
\hline $\begin{array}{l}\text { NEW ENGLAND } \\
\text { Maine } \\
\text { N.H. } \\
\text { Vt. } \\
\text { Mass. } \\
\text { R.I. } \\
\text { Conn. }\end{array}$ & $\begin{array}{r}1,436 \\
52 \\
36 \\
16 \\
599 \\
102 \\
631\end{array}$ & $\begin{array}{r}1,486 \\
28 \\
35 \\
12 \\
753 \\
97 \\
561\end{array}$ & $\begin{array}{r}25,536 \\
1,652 \\
1,037 \\
1,001 \\
10,845 \\
2,767 \\
8,234\end{array}$ & $\begin{array}{r}26,111 \\
1,649 \\
1,466 \\
881 \\
10,319 \\
2,612 \\
9,184\end{array}$ & $\begin{array}{c}- \\
\mathrm{N} \\
- \\
- \\
- \\
-\end{array}$ & $\begin{array}{l}- \\
\mathrm{N} \\
- \\
- \\
- \\
-\end{array}$ & $\begin{array}{r}163 \\
19 \\
11 \\
31 \\
69 \\
16 \\
17\end{array}$ & $\begin{array}{r}187 \\
11 \\
29 \\
33 \\
76 \\
21 \\
17\end{array}$ & $\begin{array}{l}6 \\
- \\
- \\
- \\
- \\
- \\
6\end{array}$ & $\begin{array}{r}27 \\
- \\
- \\
- \\
18 \\
- \\
9\end{array}$ \\
\hline $\begin{array}{l}\text { MID. ATLANTIC } \\
\text { Upstate N.Y. } \\
\text { N.Y. City } \\
\text { N.J. } \\
\text { Pa. }\end{array}$ & $\begin{array}{l}9,714 \\
1,007 \\
5,201 \\
1,448 \\
2,058\end{array}$ & $\begin{array}{l}9,061 \\
1,022 \\
5,280 \\
1,306 \\
1,453\end{array}$ & $\begin{array}{r}105,938 \\
18,877 \\
32,452 \\
13,679 \\
40,930\end{array}$ & $\begin{array}{l}87,844 \\
15,738 \\
28,619 \\
13,396 \\
30,091\end{array}$ & $\begin{array}{c}\bar{N} \\
- \\
- \\
N\end{array}$ & $\begin{array}{c}- \\
\mathrm{N} \\
- \\
-\end{array}$ & $\begin{array}{r}385 \\
129 \\
94 \\
7 \\
155\end{array}$ & $\begin{array}{r}397 \\
134 \\
142 \\
15 \\
106\end{array}$ & $\begin{array}{r}186 \\
7 \\
- \\
31 \\
148\end{array}$ & $\begin{array}{r}131 \\
44 \\
28 \\
23 \\
36\end{array}$ \\
\hline $\begin{array}{l}\text { E.N. CENTRAL } \\
\text { Ohio } \\
\text { Ind. } \\
\text { III. } \\
\text { Mich. } \\
\text { Wis. }\end{array}$ & $\begin{array}{r}3,863 \\
757 \\
514 \\
1,718 \\
703 \\
171\end{array}$ & $\begin{array}{r}4,216 \\
757 \\
483 \\
2,092 \\
706 \\
178\end{array}$ & $\begin{array}{r}130,427 \\
29,145 \\
15,499 \\
41,303 \\
29,796 \\
14,684\end{array}$ & $\begin{array}{r}143,967 \\
36,052 \\
16,368 \\
45,610 \\
29,875 \\
16,062\end{array}$ & $\begin{array}{c}7 \\
- \\
\mathrm{N} \\
- \\
7 \\
-\end{array}$ & $\begin{array}{r}22 \\
- \\
\mathrm{N} \\
2 \\
20 \\
-\end{array}$ & $\begin{array}{r}943 \\
169 \\
105 \\
85 \\
135 \\
449\end{array}$ & $\begin{array}{r}931 \\
118 \\
56 \\
119 \\
128 \\
510\end{array}$ & $\begin{array}{r}119 \\
106 \\
1 \\
2 \\
10 \\
-\end{array}$ & $\begin{array}{r}1,505 \\
326 \\
18 \\
554 \\
556 \\
51\end{array}$ \\
\hline $\begin{array}{l}\text { W.N. CENTRAL } \\
\text { Minn. } \\
\text { lowa } \\
\text { Mo. } \\
\text { N. Dak. } \\
\text { S. Dak. } \\
\text { Nebr.ף } \\
\text { Kans. }\end{array}$ & $\begin{array}{r}768 \\
162 \\
82 \\
365 \\
2 \\
14 \\
52 \\
91\end{array}$ & $\begin{array}{r}712 \\
149 \\
81 \\
335 \\
3 \\
10 \\
66 \\
68\end{array}$ & $\begin{array}{r}44,295 \\
9,115 \\
3,344 \\
16,971 \\
1,294 \\
2,492 \\
4,550 \\
6,529\end{array}$ & $\begin{array}{r}44,264 \\
9,612 \\
5,397 \\
15,148 \\
1,131 \\
2,083 \\
4,397 \\
6,496\end{array}$ & $\begin{array}{c}1 \\
N \\
N \\
- \\
N \\
- \\
1 \\
N\end{array}$ & $\begin{array}{r}1 \\
N \\
N \\
- \\
N \\
- \\
1 \\
N\end{array}$ & $\begin{array}{r}550 \\
144 \\
118 \\
48 \\
13 \\
40 \\
18 \\
169\end{array}$ & $\begin{array}{r}403 \\
194 \\
45 \\
38 \\
24 \\
35 \\
51 \\
16\end{array}$ & $\begin{array}{r}369 \\
49 \\
78 \\
34 \\
9 \\
65 \\
47 \\
87\end{array}$ & $\begin{array}{r}192 \\
17 \\
- \\
107 \\
- \\
14 \\
35 \\
19\end{array}$ \\
\hline $\begin{array}{l}\text { S. ATLANTIC } \\
\text { Del. } \\
\text { Md. } \\
\text { D.C. } \\
\text { Va. } \\
\text { W. Va. } \\
\text { N.C. } \\
\text { S.C. } \\
\text { Ga. } \\
\text { Fla. }\end{array}$ & $\begin{array}{r}11,498 \\
202 \\
1,441 \\
863 \\
856 \\
86 \\
1,060 \\
756 \\
1,825 \\
4,409\end{array}$ & $\begin{array}{r}11,380 \\
181 \\
1,670 \\
769 \\
811 \\
79 \\
952 \\
777 \\
1,543 \\
4,598\end{array}$ & $\begin{array}{r}145,550 \\
2,824 \\
15,837 \\
3,016 \\
15,969 \\
2,427 \\
24,319 \\
15,303 \\
28,339 \\
37,516\end{array}$ & $\begin{array}{r}148,216 \\
2,513 \\
15,658 \\
3,165 \\
17,271 \\
2,330 \\
23,309 \\
13,801 \\
30,913 \\
39,256\end{array}$ & $\begin{array}{r}5 \\
\mathrm{~N} \\
5 \\
- \\
- \\
\mathrm{N} \\
\mathrm{N} \\
- \\
- \\
\mathrm{N}\end{array}$ & $\begin{array}{c}4 \\
\mathrm{~N} \\
4 \\
- \\
- \\
\mathrm{N} \\
\mathrm{N} \\
- \\
- \\
\mathrm{N}\end{array}$ & $\begin{array}{r}385 \\
4 \\
23 \\
17 \\
45 \\
4 \\
49 \\
8 \\
124 \\
111\end{array}$ & $\begin{array}{r}311 \\
3 \\
19 \\
5 \\
24 \\
2 \\
35 \\
6 \\
117 \\
100\end{array}$ & $\begin{array}{r}180 \\
12 \\
51 \\
- \\
17 \\
1 \\
- \\
2 \\
46 \\
51\end{array}$ & $\begin{array}{r}69 \\
- \\
21 \\
- \\
- \\
2 \\
- \\
1 \\
21 \\
24\end{array}$ \\
\hline $\begin{array}{l}\text { E.S. CENTRAL } \\
\text { Ky. } \\
\text { Tenn. } \\
\text { Ala. } \\
\text { Miss. }\end{array}$ & $\begin{array}{r}1,879 \\
200 \\
800 \\
441 \\
438\end{array}$ & $\begin{array}{r}1,829 \\
287 \\
745 \\
389 \\
408\end{array}$ & $\begin{array}{r}48,413 \\
7,483 \\
19,057 \\
11,245 \\
10,628\end{array}$ & $\begin{array}{r}49,062 \\
8,310 \\
15,140 \\
14,863 \\
10,749\end{array}$ & $\begin{array}{l}\mathrm{N} \\
\mathrm{N} \\
\mathrm{N} \\
- \\
\mathrm{N}\end{array}$ & $\begin{array}{r}\mathrm{N} \\
\mathrm{N} \\
\mathrm{N} \\
- \\
\mathrm{N}\end{array}$ & $\begin{array}{r}114 \\
24 \\
38 \\
42 \\
10\end{array}$ & $\begin{array}{r}119 \\
8 \\
55 \\
46 \\
10\end{array}$ & $\begin{array}{r}44 \\
11 \\
17 \\
16 \\
-\end{array}$ & $\begin{array}{r}274 \\
42 \\
8 \\
34 \\
190\end{array}$ \\
\hline $\begin{array}{l}\text { W.S. CENTRAL } \\
\text { Ark. } \\
\text { La. } \\
\text { Okla. } \\
\text { Tex. }\end{array}$ & $\begin{array}{r}4,566 \\
172 \\
610 \\
202 \\
3,582\end{array}$ & $\begin{array}{r}3,834 \\
224 \\
898 \\
180 \\
2,532\end{array}$ & $\begin{array}{r}95,166 \\
7,251 \\
16,682 \\
10,358 \\
60,875\end{array}$ & $\begin{array}{r}101,461 \\
6,903 \\
17,749 \\
10,345 \\
66,464\end{array}$ & $\begin{array}{l}4 \\
- \\
N \\
N \\
4\end{array}$ & $\begin{array}{r}12 \\
- \\
N \\
N \\
12\end{array}$ & $\begin{array}{r}88 \\
17 \\
2 \\
19 \\
50\end{array}$ & $\begin{array}{r}62 \\
8 \\
10 \\
16 \\
28\end{array}$ & $\begin{array}{r}495 \\
22 \\
47 \\
25 \\
401\end{array}$ & $\begin{array}{r}420 \\
12 \\
204 \\
- \\
204\end{array}$ \\
\hline $\begin{array}{l}\text { MOUNTAIN } \\
\text { Mont. } \\
\text { Idaho } \\
\text { Wyo. } \\
\text { Colo. } \\
\text { N. Mex. } \\
\text { Ariz. } \\
\text { Utah } \\
\text { Nev. }\end{array}$ & $\begin{array}{r}1,461 \\
13 \\
24 \\
7 \\
343 \\
102 \\
646 \\
72 \\
254\end{array}$ & $\begin{array}{r}1,307 \\
11 \\
28 \\
8 \\
283 \\
81 \\
551 \\
62 \\
283\end{array}$ & $\begin{array}{r}41,610 \\
2,080 \\
2,374 \\
908 \\
10,031 \\
6,284 \\
11,818 \\
3,274 \\
4,841\end{array}$ & $\begin{array}{r}48,631 \\
2,138 \\
2,364 \\
875 \\
13,385 \\
6,921 \\
14,063 \\
3,257 \\
5,628\end{array}$ & $\begin{array}{r}2,461 \\
N \\
N \\
1 \\
N \\
8 \\
2,399 \\
19 \\
34\end{array}$ & $\begin{array}{r}2,378 \\
\mathrm{~N} \\
\mathrm{~N} \\
- \\
\mathrm{N} \\
8 \\
2,315 \\
11 \\
44\end{array}$ & $\begin{array}{r}129 \\
18 \\
27 \\
5 \\
34 \\
10 \\
6 \\
21 \\
8\end{array}$ & $\begin{array}{r}153 \\
6 \\
28 \\
9 \\
57 \\
19 \\
16 \\
14 \\
4\end{array}$ & $\begin{array}{r}382 \\
216 \\
- \\
94 \\
- \\
68 \\
1 \\
1 \\
2\end{array}$ & $\begin{array}{l}3 \\
1 \\
1 \\
- \\
- \\
- \\
1 \\
- \\
-\end{array}$ \\
\hline $\begin{array}{l}\text { PACIFIC } \\
\text { Wash. } \\
\text { Oreg. } \\
\text { Calif. } \\
\text { Alaska } \\
\text { Hawaii }\end{array}$ & $\begin{array}{r}6,647 \\
491 \\
242 \\
5,802 \\
15 \\
97\end{array}$ & $\begin{array}{r}4,882 \\
441 \\
310 \\
3,993 \\
30 \\
108\end{array}$ & $\begin{array}{r}134,667 \\
15,610 \\
6,940 \\
105,254 \\
3,412 \\
3,451\end{array}$ & $\begin{array}{r}130,985 \\
13,975 \\
6,515 \\
102,727 \\
3,507 \\
4,261\end{array}$ & $\begin{array}{r}1,514 \\
\mathrm{~N} \\
- \\
1,514 \\
- \\
-\end{array}$ & $\begin{array}{r}1,416 \\
\mathrm{~N} \\
- \\
1,416 \\
- \\
-\end{array}$ & $\begin{array}{r}354 \\
59 \\
38 \\
256 \\
1 \\
-\end{array}$ & $\begin{array}{r}270 \\
36 \\
39 \\
192 \\
1 \\
2\end{array}$ & $\begin{array}{l}4 \\
- \\
4 \\
- \\
- \\
-\end{array}$ & $\begin{array}{l}- \\
- \\
- \\
- \\
-\end{array}$ \\
\hline $\begin{array}{l}\text { Guam } \\
\text { P.R. } \\
\text { V.I. } \\
\text { Amer. Samoa } \\
\text { C.N.M.I. }\end{array}$ & $\begin{array}{r}6 \\
1,025 \\
33 \\
U \\
2\end{array}$ & $\begin{array}{r}2 \\
1,042 \\
70 \\
U \\
U\end{array}$ & $\begin{array}{r}- \\
1,761 \\
208 \\
U \\
-\end{array}$ & $\begin{array}{r}606 \\
2,390 \\
125 \\
\cup \\
U\end{array}$ & $\begin{array}{l}- \\
\text { N } \\
- \\
\text { U } \\
-\end{array}$ & $\begin{array}{l}- \\
\mathrm{N} \\
- \\
\mathrm{U}\end{array}$ & $\begin{array}{c}- \\
\text { N } \\
- \\
\\
-\end{array}$ & $\begin{array}{l}- \\
\bar{N} \\
\bar{U}\end{array}$ & $\begin{array}{l}- \\
- \\
\\
\end{array}$ & $\begin{array}{l}- \\
- \\
- \\
U\end{array}$ \\
\hline
\end{tabular}

$\mathrm{N}$ : Not notifiable. U: Unavailable. $\quad-:$ No reported cases. $\quad$ C.N.M.I.: Commonwealth of Northern Mariana Islands.

* Incidence data for reporting years 2002 and 2003 are provisional and cumulative (year-to-date).

† Chlamydia refers to genital infections caused by $C$. trachomatis.

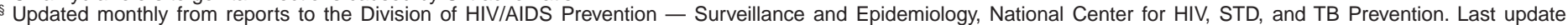
November 30, 2003

^ Contains data reported through National Electronic Disease Surveillance System (NEDSS). 
TABLE II. (Continued) Provisional cases of selected notifiable diseases, United States, weeks ending December 6, 2003, and December 7, 2002 (49th Week)*

\begin{tabular}{|c|c|c|c|c|c|c|c|c|c|c|}
\hline \multirow[b]{3}{*}{ Reporting area } & \multicolumn{6}{|c|}{ Escherichia coli, Enterohemorrhagic (EHEC) } & \multirow{2}{*}{\multicolumn{2}{|c|}{ Giardiasis }} & \multirow{2}{*}{\multicolumn{2}{|c|}{ Gonorrhea }} \\
\hline & \multicolumn{2}{|c|}{ O157:H7 } & \multicolumn{2}{|c|}{$\begin{array}{l}\text { Shiga toxin positive, } \\
\text { serogroup non-0157 }\end{array}$} & \multicolumn{2}{|c|}{$\begin{array}{c}\text { Shiga toxin positive, } \\
\text { not serogrouped }\end{array}$} & & & & \\
\hline & $\begin{array}{l}\text { Cum. } \\
2003\end{array}$ & $\begin{array}{l}\text { Cum. } \\
2002\end{array}$ & $\begin{array}{l}\text { Cum. } \\
2003\end{array}$ & $\begin{array}{l}\text { Cum. } \\
2002\end{array}$ & $\begin{array}{l}\text { Cum. } \\
2003\end{array}$ & $\begin{array}{l}\text { Cum. } \\
2002\end{array}$ & $\begin{array}{l}\text { Cum. } \\
2003 \\
\end{array}$ & $\begin{array}{l}\text { Cum. } \\
2002\end{array}$ & $\begin{array}{l}\text { Cum. } \\
2003\end{array}$ & $\begin{array}{l}\text { Cum } \\
2002 \\
\end{array}$ \\
\hline UNITED STATES & 2,438 & 3,606 & 258 & 183 & 126 & 51 & 17,130 & 19,593 & 293,826 & 331,185 \\
\hline $\begin{array}{l}\text { NEW ENGLAND } \\
\text { Maine } \\
\text { N.H. } \\
\text { Vt. } \\
\text { Mass. } \\
\text { R.I. } \\
\text { Conn. }\end{array}$ & $\begin{array}{r}154 \\
10 \\
12 \\
18 \\
64 \\
1 \\
49\end{array}$ & $\begin{array}{r}258 \\
37 \\
33 \\
14 \\
117 \\
12 \\
45\end{array}$ & $\begin{array}{r}54 \\
3 \\
2 \\
- \\
8 \\
- \\
41\end{array}$ & $\begin{array}{r}46 \\
8 \\
- \\
1 \\
19 \\
1 \\
17\end{array}$ & $\begin{array}{r}16 \\
1 \\
- \\
- \\
15 \\
- \\
-\end{array}$ & $\begin{array}{l}6 \\
- \\
- \\
1 \\
5 \\
- \\
-\end{array}$ & $\begin{array}{r}1,319 \\
178 \\
22 \\
116 \\
677 \\
106 \\
220\end{array}$ & $\begin{array}{r}1,666 \\
198 \\
41 \\
138 \\
901 \\
145 \\
243\end{array}$ & $\begin{array}{r}6,754 \\
170 \\
76 \\
83 \\
2,879 \\
892 \\
2,654\end{array}$ & $\begin{array}{r}7,296 \\
130 \\
116 \\
94 \\
3,071 \\
864 \\
3,021\end{array}$ \\
\hline $\begin{array}{l}\text { MID. ATLANTIC } \\
\text { Upstate N.Y. } \\
\text { N.Y. City } \\
\text { N.J. } \\
\text { Pa. }\end{array}$ & $\begin{array}{r}230 \\
92 \\
5 \\
22 \\
111\end{array}$ & $\begin{array}{r}403 \\
165 \\
18 \\
62 \\
158\end{array}$ & $\begin{array}{r}19 \\
11 \\
- \\
1 \\
7\end{array}$ & $\begin{array}{l}1 \\
- \\
- \\
- \\
1\end{array}$ & $\begin{array}{r}35 \\
17 \\
- \\
- \\
18\end{array}$ & $\begin{array}{l}7 \\
- \\
- \\
1 \\
6\end{array}$ & $\begin{array}{r}3,392 \\
1,015 \\
1,075 \\
351 \\
951\end{array}$ & $\begin{array}{r}3,997 \\
1,177 \\
1,369 \\
455 \\
996\end{array}$ & $\begin{array}{r}40,725 \\
7,415 \\
12,794 \\
7,634 \\
12,882\end{array}$ & $\begin{array}{r}40,024 \\
8,119 \\
11,970 \\
7,374 \\
12,561\end{array}$ \\
\hline $\begin{array}{l}\text { E.N. CENTRAL } \\
\text { Ohio } \\
\text { Ind. } \\
\text { III. } \\
\text { Mich. } \\
\text { Wis. }\end{array}$ & $\begin{array}{r}550 \\
130 \\
89 \\
112 \\
89 \\
130\end{array}$ & $\begin{array}{r}834 \\
152 \\
76 \\
189 \\
133 \\
284\end{array}$ & $\begin{array}{r}25 \\
17 \\
- \\
- \\
- \\
8\end{array}$ & $\begin{array}{r}31 \\
11 \\
1 \\
6 \\
3 \\
10\end{array}$ & $\begin{array}{r}23 \\
22 \\
- \\
- \\
- \\
1\end{array}$ & $\begin{array}{l}6 \\
5 \\
- \\
- \\
1 \\
-\end{array}$ & $\begin{array}{r}2,836 \\
864 \\
- \\
721 \\
722 \\
529\end{array}$ & $\begin{array}{r}3,433 \\
898 \\
- \\
982 \\
882 \\
671\end{array}$ & $\begin{array}{r}58,576 \\
16,108 \\
6,210 \\
18,623 \\
12,869 \\
4,766\end{array}$ & $\begin{array}{r}70,335 \\
20,757 \\
7,052 \\
22,913 \\
13,640 \\
5,973\end{array}$ \\
\hline $\begin{array}{l}\text { W.N. CENTRAL } \\
\text { Minn. } \\
\text { lowa } \\
\text { Mo. } \\
\text { N. Dak. } \\
\text { S. Dak. } \\
\text { Nebr. } \\
\text { Kans. }\end{array}$ & $\begin{array}{r}423 \\
132 \\
102 \\
87 \\
13 \\
28 \\
33 \\
28\end{array}$ & $\begin{array}{r}501 \\
158 \\
120 \\
68 \\
18 \\
40 \\
66 \\
31\end{array}$ & $\begin{array}{r}54 \\
23 \\
- \\
18 \\
4 \\
4 \\
4 \\
1\end{array}$ & $\begin{array}{r}31 \\
26 \\
- \\
- \\
- \\
2 \\
3 \\
-\end{array}$ & $\begin{array}{r}20 \\
1 \\
- \\
1 \\
8 \\
- \\
- \\
10\end{array}$ & $\begin{array}{l}7 \\
- \\
- \\
- \\
2 \\
- \\
- \\
5\end{array}$ & $\begin{array}{r}1,918 \\
755 \\
256 \\
477 \\
38 \\
82 \\
109 \\
201\end{array}$ & $\begin{array}{r}2,029 \\
785 \\
300 \\
482 \\
31 \\
80 \\
172 \\
179\end{array}$ & $\begin{array}{r}15,702 \\
2,608 \\
775 \\
8,067 \\
72 \\
222 \\
1,544 \\
2,414\end{array}$ & $\begin{array}{r}17,051 \\
2,921 \\
1,290 \\
8,389 \\
71 \\
259 \\
1,455 \\
2,666\end{array}$ \\
\hline $\begin{array}{l}\text { S. ATLANTIC } \\
\text { Del. } \\
\text { Md. } \\
\text { D.C. } \\
\text { Va. } \\
\text { W. Va. } \\
\text { N.C. } \\
\text { S.C. } \\
\text { Ga. } \\
\text { Fla. }\end{array}$ & $\begin{array}{r}148 \\
11 \\
14 \\
1 \\
37 \\
5 \\
4 \\
2 \\
31 \\
43\end{array}$ & $\begin{array}{r}413 \\
9 \\
27 \\
3 \\
67 \\
9 \\
191 \\
5 \\
43 \\
59\end{array}$ & $\begin{array}{r}70 \\
N \\
- \\
- \\
11 \\
- \\
30 \\
- \\
5 \\
24\end{array}$ & $\begin{array}{r}36 \\
N \\
- \\
- \\
10 \\
- \\
- \\
- \\
8 \\
18\end{array}$ & $\begin{array}{r}11 \\
\mathrm{~N} \\
- \\
- \\
- \\
- \\
- \\
- \\
- \\
11\end{array}$ & $\begin{array}{r}1 \\
N \\
- \\
- \\
- \\
1 \\
- \\
- \\
- \\
-\end{array}$ & $\begin{array}{r}2,653 \\
46 \\
113 \\
49 \\
344 \\
49 \\
\mathrm{~N} \\
134 \\
879 \\
1,039\end{array}$ & $\begin{array}{r}2,787 \\
54 \\
109 \\
43 \\
307 \\
57 \\
\mathrm{~N} \\
135 \\
868 \\
1,214\end{array}$ & $\begin{array}{r}72,361 \\
1,064 \\
7,565 \\
2,388 \\
7,311 \\
801 \\
14,014 \\
8,212 \\
14,321 \\
16,685\end{array}$ & $\begin{array}{r}84,136 \\
1,503 \\
8,645 \\
2,518 \\
9,885 \\
921 \\
14,867 \\
8,816 \\
16,905 \\
20,076\end{array}$ \\
\hline $\begin{array}{l}\text { E.S. CENTRAL } \\
\text { Ky. } \\
\text { Tenn. } \\
\text { Ala. } \\
\text { Miss. }\end{array}$ & $\begin{array}{r}80 \\
27 \\
34 \\
13 \\
6\end{array}$ & $\begin{array}{r}106 \\
30 \\
46 \\
19 \\
11\end{array}$ & $\begin{array}{l}2 \\
2 \\
- \\
- \\
-\end{array}$ & $\begin{array}{l}- \\
- \\
- \\
-\end{array}$ & $\begin{array}{l}7 \\
7 \\
- \\
- \\
-\end{array}$ & $\begin{array}{r}10 \\
10 \\
- \\
- \\
-\end{array}$ & $\begin{array}{r}331 \\
\mathrm{~N} \\
172 \\
159 \\
-\end{array}$ & $\begin{array}{r}380 \\
N \\
181 \\
199 \\
-\end{array}$ & $\begin{array}{r}23,963 \\
3,333 \\
7,949 \\
7,211 \\
5,470\end{array}$ & $\begin{array}{r}28,398 \\
3,571 \\
8,868 \\
9,618 \\
6,341\end{array}$ \\
\hline $\begin{array}{l}\text { W.S. CENTRAL } \\
\text { Ark. } \\
\text { La. } \\
\text { Okla. } \\
\text { Tex. }\end{array}$ & $\begin{array}{r}92 \\
12 \\
3 \\
28 \\
49\end{array}$ & $\begin{array}{r}108 \\
12 \\
4 \\
22 \\
70\end{array}$ & $\begin{array}{l}4 \\
- \\
- \\
- \\
4\end{array}$ & $\begin{array}{l}2 \\
- \\
- \\
- \\
2\end{array}$ & $\begin{array}{l}9 \\
- \\
- \\
- \\
9\end{array}$ & $\begin{array}{l}9 \\
- \\
- \\
- \\
9\end{array}$ & $\begin{array}{r}280 \\
138 \\
10 \\
128 \\
4\end{array}$ & $\begin{array}{r}246 \\
166 \\
6 \\
71 \\
3\end{array}$ & $\begin{array}{r}39,186 \\
3,664 \\
9,891 \\
4,264 \\
21,367\end{array}$ & $\begin{array}{r}45,460 \\
4,371 \\
10,970 \\
4,449 \\
25,670\end{array}$ \\
\hline $\begin{array}{l}\text { MOUNTAIN } \\
\text { Mont. } \\
\text { Idaho } \\
\text { Wyo. } \\
\text { Colo. } \\
\text { N. Mex. } \\
\text { Ariz. } \\
\text { Utah } \\
\text { Nev. }\end{array}$ & $\begin{array}{r}319 \\
16 \\
81 \\
4 \\
71 \\
10 \\
39 \\
75 \\
23\end{array}$ & $\begin{array}{r}331 \\
30 \\
42 \\
14 \\
97 \\
12 \\
33 \\
75 \\
28\end{array}$ & $\begin{array}{r}26 \\
- \\
16 \\
1 \\
3 \\
5 \\
\mathrm{~N} \\
- \\
1\end{array}$ & $\begin{array}{r}29 \\
- \\
18 \\
2 \\
6 \\
3 \\
\mathrm{~N} \\
- \\
-\end{array}$ & $\begin{array}{l}5 \\
- \\
- \\
- \\
5 \\
- \\
\mathrm{N} \\
- \\
-\end{array}$ & $\begin{array}{r}5 \\
- \\
- \\
- \\
5 \\
- \\
\mathrm{N} \\
- \\
-\end{array}$ & $\begin{array}{r}1,532 \\
106 \\
195 \\
22 \\
418 \\
48 \\
253 \\
355 \\
135\end{array}$ & $\begin{array}{r}1,601 \\
92 \\
127 \\
29 \\
548 \\
146 \\
189 \\
316 \\
154\end{array}$ & $\begin{array}{r}8,974 \\
104 \\
69 \\
42 \\
2,408 \\
1,007 \\
3,241 \\
344 \\
1,759\end{array}$ & $\begin{array}{r}10,675 \\
108 \\
90 \\
57 \\
3,323 \\
1,391 \\
3,499 \\
341 \\
1,866\end{array}$ \\
\hline $\begin{array}{l}\text { PACIFIC } \\
\text { Wash. } \\
\text { Oreg. } \\
\text { Calif. } \\
\text { Alaska } \\
\text { Hawaii }\end{array}$ & $\begin{array}{r}442 \\
112 \\
98 \\
220 \\
4 \\
8\end{array}$ & $\begin{array}{r}652 \\
139 \\
204 \\
265 \\
7 \\
37\end{array}$ & $\begin{array}{l}4 \\
1 \\
3 \\
- \\
- \\
-\end{array}$ & $\begin{array}{l}7 \\
- \\
7 \\
- \\
- \\
-\end{array}$ & $\begin{array}{l}- \\
- \\
- \\
- \\
-\end{array}$ & $\begin{array}{l}- \\
- \\
- \\
- \\
-\end{array}$ & $\begin{array}{r}2,869 \\
330 \\
382 \\
1,989 \\
83 \\
85\end{array}$ & $\begin{array}{r}3,454 \\
414 \\
427 \\
2,417 \\
111 \\
85\end{array}$ & $\begin{array}{r}27,585 \\
2,562 \\
924 \\
22,759 \\
512 \\
828\end{array}$ & $\begin{array}{r}27,810 \\
2,742 \\
836 \\
22,946 \\
591 \\
695\end{array}$ \\
\hline $\begin{array}{l}\text { Guam } \\
\text { P.R. } \\
\text { V.I. } \\
\text { Amer. Samoa } \\
\text { C.N.M.I. }\end{array}$ & $\begin{array}{l}N \\
- \\
- \\
\end{array}$ & $\begin{array}{c}N \\
1 \\
- \\
U \\
U\end{array}$ & $\begin{array}{c}- \\
- \\
\end{array}$ & $\begin{array}{l}- \\
- \\
\text { U } \\
U\end{array}$ & $\begin{array}{r}36 \\
\bar{U} \\
-\end{array}$ & $\begin{array}{l}- \\
- \\
\text { U }\end{array}$ & $\begin{array}{r}- \\
129 \\
- \\
\text { U }\end{array}$ & $\begin{array}{r}7 \\
81 \\
- \\
U \\
U\end{array}$ & $\begin{array}{r}- \\
188 \\
55 \\
U \\
-\end{array}$ & $\begin{array}{r}45 \\
327 \\
31 \\
U \\
U\end{array}$ \\
\hline
\end{tabular}

$\mathrm{N}$ : Not notifiable. 
TABLE II. (Continued) Provisional cases of selected notifiable diseases, United States, weeks ending December 6, 2003, and December 7, 2002 (49th Week)*

\begin{tabular}{|c|c|c|c|c|c|c|c|c|c|c|}
\hline \multirow[b]{4}{*}{ Reporting area } & \multicolumn{8}{|c|}{ Haemophilus influenzae, invasive ${ }^{\dagger}$} & \multirow{3}{*}{\multicolumn{2}{|c|}{$\begin{array}{c}\begin{array}{c}\text { Hepatitis } \\
\text { (viral, acute), by type }\end{array} \\
\text { A }\end{array}$}} \\
\hline & \multirow{2}{*}{\multicolumn{2}{|c|}{$\begin{array}{c}\text { All ages } \\
\text { All serotypes }\end{array}$}} & \multicolumn{6}{|c|}{ Age $<5$ years } & & \\
\hline & & & \multicolumn{2}{|c|}{ Serotype b } & \multicolumn{2}{|c|}{ Non-serotype b } & \multicolumn{2}{|c|}{ Unknown serotype } & & \\
\hline & $\begin{array}{l}\text { Cum. } \\
2003 \\
\end{array}$ & $\begin{array}{l}\text { Cum. } \\
2002 \\
\end{array}$ & $\begin{array}{l}\text { Cum. } \\
2003 \\
\end{array}$ & $\begin{array}{l}\text { Cum. } \\
2002 \\
\end{array}$ & $\begin{array}{l}\text { Cum. } \\
2003 \\
\end{array}$ & $\begin{array}{l}\text { Cum. } \\
2002 \\
\end{array}$ & $\begin{array}{l}\text { Cum. } \\
2003 \\
\end{array}$ & $\begin{array}{l}\text { Cum. } \\
2002 \\
\end{array}$ & $\begin{array}{l}\text { Cum. } \\
2003 \\
\end{array}$ & $\begin{array}{l}\text { Cum. } \\
2002 \\
\end{array}$ \\
\hline UNITED STATES & 1,560 & 1,558 & 20 & 29 & 87 & 132 & 174 & 143 & 6,857 & 8,323 \\
\hline $\begin{array}{l}\text { NEW ENGLAND } \\
\text { Maine } \\
\text { N.H. } \\
\text { Vt. } \\
\text { Mass. } \\
\text { R.I. } \\
\text { Conn. }\end{array}$ & $\begin{array}{r}114 \\
4 \\
11 \\
9 \\
50 \\
9 \\
31\end{array}$ & $\begin{array}{r}116 \\
2 \\
10 \\
7 \\
43 \\
10 \\
44\end{array}$ & $\begin{array}{l}1 \\
- \\
1 \\
- \\
- \\
- \\
-\end{array}$ & $\begin{array}{l}- \\
- \\
- \\
- \\
- \\
-\end{array}$ & $\begin{array}{l}5 \\
- \\
- \\
- \\
5 \\
- \\
-\end{array}$ & $\begin{array}{r}11 \\
- \\
- \\
- \\
4 \\
- \\
7\end{array}$ & $\begin{array}{l}5 \\
1 \\
- \\
- \\
3 \\
1 \\
-\end{array}$ & $\begin{array}{l}2 \\
- \\
- \\
- \\
2 \\
- \\
-\end{array}$ & $\begin{array}{r}307 \\
18 \\
11 \\
6 \\
186 \\
15 \\
71\end{array}$ & $\begin{array}{r}286 \\
8 \\
11 \\
4 \\
141 \\
30 \\
92\end{array}$ \\
\hline $\begin{array}{l}\text { MID. ATLANTIC } \\
\text { Upstate N.Y. } \\
\text { N.Y. City } \\
\text { N.J. } \\
\text { Pa. }\end{array}$ & $\begin{array}{r}347 \\
126 \\
57 \\
60 \\
104\end{array}$ & $\begin{array}{r}284 \\
109 \\
66 \\
54 \\
55\end{array}$ & $\begin{array}{l}- \\
- \\
- \\
-\end{array}$ & $\begin{array}{l}3 \\
2 \\
- \\
- \\
1\end{array}$ & $\begin{array}{l}2 \\
2 \\
- \\
- \\
-\end{array}$ & $\begin{array}{r}15 \\
4 \\
- \\
- \\
11\end{array}$ & $\begin{array}{l}50 \\
13 \\
10 \\
10 \\
17\end{array}$ & $\begin{array}{r}23 \\
8 \\
9 \\
6 \\
-\end{array}$ & $\begin{array}{r}1,699 \\
141 \\
422 \\
149 \\
987\end{array}$ & $\begin{array}{r}1,070 \\
174 \\
431 \\
178 \\
287\end{array}$ \\
\hline $\begin{array}{l}\text { E.N. CENTRAL } \\
\text { Ohio } \\
\text { Ind. } \\
\text { III. } \\
\text { Mich. } \\
\text { Wis. }\end{array}$ & $\begin{array}{r}226 \\
67 \\
48 \\
69 \\
21 \\
21\end{array}$ & $\begin{array}{r}301 \\
75 \\
41 \\
117 \\
17 \\
51\end{array}$ & $\begin{array}{l}4 \\
- \\
1 \\
- \\
3 \\
-\end{array}$ & $\begin{array}{l}3 \\
- \\
1 \\
- \\
2 \\
-\end{array}$ & $\begin{array}{r}12 \\
- \\
8 \\
- \\
4 \\
-\end{array}$ & $\begin{array}{r}14 \\
1 \\
8 \\
- \\
5 \\
-\end{array}$ & $\begin{array}{r}32 \\
11 \\
- \\
15 \\
1 \\
5\end{array}$ & $\begin{array}{r}42 \\
9 \\
- \\
20 \\
- \\
13\end{array}$ & $\begin{array}{r}670 \\
161 \\
75 \\
191 \\
200 \\
43\end{array}$ & $\begin{array}{r}1,006 \\
291 \\
48 \\
259 \\
215 \\
193\end{array}$ \\
\hline $\begin{array}{l}\text { W.N. CENTRAL } \\
\text { Minn. } \\
\text { lowa } \\
\text { Mo. } \\
\text { N. Dak. } \\
\text { S. Dak. } \\
\text { Nebr. } \\
\text { Kans. }\end{array}$ & $\begin{array}{r}118 \\
52 \\
- \\
40 \\
3 \\
1 \\
3 \\
19\end{array}$ & $\begin{array}{r}71 \\
47 \\
1 \\
13 \\
4 \\
1 \\
- \\
5\end{array}$ & $\begin{array}{l}2 \\
2 \\
- \\
- \\
- \\
- \\
- \\
-\end{array}$ & $\begin{array}{l}1 \\
1 \\
- \\
- \\
- \\
- \\
- \\
-\end{array}$ & $\begin{array}{l}7 \\
7 \\
- \\
- \\
- \\
- \\
- \\
-\end{array}$ & $\begin{array}{l}3 \\
3 \\
- \\
- \\
- \\
- \\
- \\
-\end{array}$ & $\begin{array}{r}15 \\
2 \\
- \\
12 \\
- \\
- \\
- \\
1\end{array}$ & $\begin{array}{l}6 \\
4 \\
- \\
2 \\
- \\
- \\
- \\
-\end{array}$ & $\begin{array}{r}186 \\
45 \\
30 \\
69 \\
1 \\
- \\
13 \\
28\end{array}$ & $\begin{array}{r}280 \\
42 \\
64 \\
82 \\
3 \\
3 \\
17 \\
69\end{array}$ \\
\hline $\begin{array}{l}\text { S. ATLANTIC } \\
\text { Del. } \\
\text { Md. } \\
\text { D.C. } \\
\text { Va. } \\
\text { W. Va. } \\
\text { N.C. } \\
\text { S.C. } \\
\text { Ga. } \\
\text { Fla. }\end{array}$ & $\begin{array}{r}363 \\
87 \\
- \\
52 \\
15 \\
36 \\
4 \\
60 \\
109\end{array}$ & $\begin{array}{r}344 \\
89 \\
- \\
32 \\
17 \\
31 \\
13 \\
78 \\
84\end{array}$ & $\begin{array}{l}3 \\
- \\
1 \\
- \\
- \\
- \\
- \\
- \\
- \\
2\end{array}$ & $\begin{array}{l}5 \\
- \\
2 \\
- \\
- \\
- \\
- \\
- \\
- \\
3\end{array}$ & $\begin{array}{r}17 \\
- \\
7 \\
- \\
- \\
- \\
3 \\
- \\
- \\
7\end{array}$ & $\begin{array}{r}16 \\
- \\
4 \\
- \\
- \\
1 \\
3 \\
- \\
- \\
8\end{array}$ & $\begin{array}{r}20 \\
- \\
1 \\
- \\
6 \\
- \\
2 \\
1 \\
5 \\
5\end{array}$ & $\begin{array}{r}27 \\
- \\
1 \\
5 \\
5 \\
1 \\
5 \\
2 \\
12 \\
6\end{array}$ & $\begin{array}{r}1,717 \\
7 \\
169 \\
43 \\
107 \\
15 \\
105 \\
38 \\
836 \\
397\end{array}$ & $\begin{array}{r}2,310 \\
15 \\
295 \\
75 \\
150 \\
20 \\
203 \\
60 \\
476 \\
1,016\end{array}$ \\
\hline $\begin{array}{l}\text { E.S. CENTRAL } \\
\text { Ky. } \\
\text { Tenn. } \\
\text { Ala. } \\
\text { Miss. }\end{array}$ & $\begin{array}{r}73 \\
6 \\
45 \\
20 \\
2\end{array}$ & $\begin{array}{r}65 \\
7 \\
32 \\
16 \\
10\end{array}$ & $\begin{array}{l}1 \\
- \\
- \\
1 \\
-\end{array}$ & $\begin{array}{l}1 \\
- \\
- \\
1 \\
-\end{array}$ & $\begin{array}{l}2 \\
2 \\
- \\
- \\
-\end{array}$ & $\begin{array}{l}5 \\
1 \\
1 \\
3 \\
-\end{array}$ & $\begin{array}{r}10 \\
- \\
6 \\
3 \\
1\end{array}$ & $\begin{array}{r}13 \\
2 \\
7 \\
1 \\
3\end{array}$ & $\begin{array}{r}246 \\
31 \\
185 \\
15 \\
15\end{array}$ & $\begin{array}{r}257 \\
41 \\
115 \\
39 \\
62\end{array}$ \\
\hline $\begin{array}{l}\text { W.S. CENTRAL } \\
\text { Ark. } \\
\text { La. } \\
\text { Okla. } \\
\text { Tex. }\end{array}$ & $\begin{array}{r}65 \\
7 \\
12 \\
43 \\
3\end{array}$ & $\begin{array}{r}58 \\
1 \\
9 \\
46 \\
2\end{array}$ & $\begin{array}{l}2 \\
- \\
- \\
- \\
2\end{array}$ & $\begin{array}{l}2 \\
- \\
- \\
- \\
2\end{array}$ & $\begin{array}{l}8 \\
1 \\
- \\
7 \\
-\end{array}$ & $\begin{array}{r}11 \\
- \\
- \\
11 \\
-\end{array}$ & $\begin{array}{l}5 \\
- \\
5 \\
- \\
-\end{array}$ & $\begin{array}{l}3 \\
- \\
3 \\
- \\
-\end{array}$ & $\begin{array}{r}366 \\
19 \\
54 \\
22 \\
271\end{array}$ & $\begin{array}{r}993 \\
68 \\
82 \\
48 \\
795\end{array}$ \\
\hline $\begin{array}{l}\text { MOUNTAIN } \\
\text { Mont. } \\
\text { Idaho } \\
\text { Wyo. } \\
\text { Colo. } \\
\text { N. Mex. } \\
\text { Ariz. } \\
\text { Utah } \\
\text { Nev. }\end{array}$ & $\begin{array}{r}156 \\
- \\
5 \\
2 \\
37 \\
17 \\
72 \\
13 \\
10\end{array}$ & $\begin{array}{r}182 \\
- \\
2 \\
2 \\
33 \\
26 \\
89 \\
18 \\
12\end{array}$ & $\begin{array}{l}4 \\
- \\
- \\
- \\
- \\
- \\
4 \\
- \\
-\end{array}$ & $\begin{array}{l}6 \\
- \\
- \\
- \\
- \\
- \\
4 \\
1 \\
1\end{array}$ & $\begin{array}{r}19 \\
- \\
- \\
- \\
- \\
4 \\
6 \\
5 \\
4\end{array}$ & $\begin{array}{r}39 \\
- \\
- \\
- \\
- \\
6 \\
27 \\
4 \\
2\end{array}$ & $\begin{array}{r}22 \\
- \\
2 \\
- \\
7 \\
1 \\
8 \\
4 \\
-\end{array}$ & $\begin{array}{r}15 \\
- \\
1 \\
- \\
3 \\
1 \\
6 \\
1 \\
3\end{array}$ & $\begin{array}{r}466 \\
8 \\
17 \\
1 \\
68 \\
20 \\
257 \\
46 \\
49\end{array}$ & $\begin{array}{r}511 \\
13 \\
30 \\
3 \\
73 \\
29 \\
261 \\
53 \\
49\end{array}$ \\
\hline $\begin{array}{l}\text { PACIFIC } \\
\text { Wash. } \\
\text { Oreg. } \\
\text { Calif. } \\
\text { Alaska } \\
\text { Hawaii }\end{array}$ & $\begin{array}{r}98 \\
11 \\
44 \\
20 \\
2 \\
21\end{array}$ & $\begin{array}{r}137 \\
3 \\
53 \\
43 \\
2 \\
36\end{array}$ & $\begin{array}{l}3 \\
- \\
- \\
3 \\
- \\
-\end{array}$ & $\begin{array}{l}8 \\
2 \\
- \\
6 \\
- \\
-\end{array}$ & $\begin{array}{r}15 \\
7 \\
- \\
8 \\
- \\
-\end{array}$ & $\begin{array}{r}18 \\
1 \\
- \\
17 \\
- \\
-\end{array}$ & $\begin{array}{r}15 \\
3 \\
5 \\
4 \\
2 \\
1\end{array}$ & $\begin{array}{r}12 \\
- \\
3 \\
4 \\
2 \\
3\end{array}$ & $\begin{array}{r}1,200 \\
63 \\
57 \\
1,059 \\
9 \\
12\end{array}$ & $\begin{array}{r}1,610 \\
145 \\
60 \\
1,370 \\
10 \\
25\end{array}$ \\
\hline $\begin{array}{l}\text { Guam } \\
\text { P.R. } \\
\text { V.I. } \\
\text { Amer. Samoa } \\
\text { C.N.M.I. }\end{array}$ & $\begin{array}{l}- \\
- \\
- \\
\end{array}$ & $\begin{array}{l}- \\
1 \\
\\
\\
\end{array}$ & $\begin{array}{l}- \\
- \\
\\
-\end{array}$ & $\begin{array}{l}- \\
- \\
- \\
U \\
\end{array}$ & $\begin{array}{l}- \\
- \\
\\
-\end{array}$ & $\begin{array}{l}- \\
- \\
\\
U \\
\end{array}$ & $\begin{array}{l}- \\
- \\
\\
-\end{array}$ & $\begin{array}{l}- \\
- \\
- \\
U \\
\end{array}$ & $\begin{array}{r}50 \\
- \\
- \\
-\end{array}$ & $\begin{array}{r}1 \\
222 \\
\bar{U} \\
U\end{array}$ \\
\hline
\end{tabular}

N: Not notifiable. 
TABLE II. (Continued) Provisional cases of selected notifiable diseases, United States, weeks ending December 6, 2003, and December 7, 2002 (49th Week)*

\begin{tabular}{|c|c|c|c|c|c|c|c|c|c|c|}
\hline \multirow[b]{3}{*}{ Reporting area } & \multicolumn{4}{|c|}{ Hepatitis (viral, acute), by type } & \multirow{2}{*}{\multicolumn{2}{|c|}{ Legionellosis }} & \multirow{2}{*}{\multicolumn{2}{|c|}{ Listeriosis }} & \multirow{2}{*}{\multicolumn{2}{|c|}{ Lyme disease }} \\
\hline & \multicolumn{2}{|c|}{ B } & \multicolumn{2}{|c|}{ C } & & & & & & \\
\hline & $\begin{array}{l}\text { Cum. } \\
2003\end{array}$ & $\begin{array}{l}\text { Cum. } \\
2002\end{array}$ & $\begin{array}{l}\text { Cum. } \\
2003\end{array}$ & $\begin{array}{l}\text { Cum. } \\
2002\end{array}$ & $\begin{array}{l}\text { Cum. } \\
2003\end{array}$ & $\begin{array}{l}\text { Cum. } \\
2002\end{array}$ & $\begin{array}{l}\text { Cum. } \\
2003\end{array}$ & $\begin{array}{l}\text { Cum. } \\
2002\end{array}$ & $\begin{array}{l}\text { Cum. } \\
2003\end{array}$ & $\begin{array}{l}\text { Cum. } \\
2002\end{array}$ \\
\hline UNITED STATES & 6,409 & 6,988 & 1,772 & 1,703 & 1,888 & 1,208 & 585 & 614 & 17,101 & 21,182 \\
\hline $\begin{array}{l}\text { NEW ENGLAND } \\
\text { Maine } \\
\text { N.H. } \\
\text { Vt. } \\
\text { Mass. } \\
\text { R.I. } \\
\text { Conn. }\end{array}$ & $\begin{array}{r}238 \\
1 \\
11 \\
4 \\
182 \\
18 \\
22\end{array}$ & $\begin{array}{r}287 \\
12 \\
22 \\
6 \\
152 \\
28 \\
67\end{array}$ & $\begin{array}{l}8 \\
1 \\
- \\
7 \\
- \\
- \\
\end{array}$ & $\begin{array}{r}20 \\
- \\
- \\
13 \\
6 \\
1 \\
U\end{array}$ & $\begin{array}{r}97 \\
2 \\
6 \\
6 \\
40 \\
15 \\
28\end{array}$ & $\begin{array}{r}110 \\
4 \\
7 \\
35 \\
44 \\
5 \\
15\end{array}$ & $\begin{array}{r}43 \\
7 \\
3 \\
1 \\
14 \\
- \\
18\end{array}$ & $\begin{array}{r}60 \\
5 \\
4 \\
3 \\
33 \\
1 \\
14\end{array}$ & $\begin{array}{r}3,275 \\
216 \\
95 \\
43 \\
1,064 \\
564 \\
1,293\end{array}$ & $\begin{array}{r}6,908 \\
102 \\
245 \\
35 \\
1,796 \\
335 \\
4,395\end{array}$ \\
\hline $\begin{array}{l}\text { MID. ATLANTIC } \\
\text { Upstate N.Y. } \\
\text { N.Y. City } \\
\text { N.J. } \\
\text { Pa. }\end{array}$ & $\begin{array}{l}823 \\
125 \\
275 \\
160 \\
263\end{array}$ & $\begin{array}{r}1,468 \\
116 \\
714 \\
318 \\
320\end{array}$ & $\begin{array}{r}157 \\
41 \\
- \\
- \\
116\end{array}$ & $\begin{array}{r}105 \\
44 \\
- \\
5 \\
56\end{array}$ & $\begin{array}{r}540 \\
151 \\
51 \\
70 \\
268\end{array}$ & $\begin{array}{r}342 \\
99 \\
62 \\
33 \\
148\end{array}$ & $\begin{array}{r}111 \\
33 \\
19 \\
15 \\
44\end{array}$ & $\begin{array}{r}183 \\
56 \\
39 \\
35 \\
53\end{array}$ & $\begin{array}{r}11,113 \\
4,353 \\
5 \\
1,967 \\
4,788\end{array}$ & $\begin{array}{r}10,874 \\
4,719 \\
58 \\
2,307 \\
3,790\end{array}$ \\
\hline $\begin{array}{l}\text { E.N. CENTRAL } \\
\text { Ohio } \\
\text { Ind. } \\
\text { III. } \\
\text { Mich. } \\
\text { Wis. }\end{array}$ & $\begin{array}{r}391 \\
138 \\
36 \\
1 \\
185 \\
31\end{array}$ & $\begin{array}{r}663 \\
103 \\
56 \\
141 \\
314 \\
49\end{array}$ & $\begin{array}{r}152 \\
12 \\
9 \\
17 \\
114 \\
-\end{array}$ & $\begin{array}{r}115 \\
2 \\
- \\
23 \\
86 \\
4\end{array}$ & $\begin{array}{r}377 \\
216 \\
25 \\
3 \\
116 \\
17\end{array}$ & $\begin{array}{r}284 \\
116 \\
21 \\
27 \\
83 \\
37\end{array}$ & $\begin{array}{r}69 \\
24 \\
10 \\
8 \\
19 \\
8\end{array}$ & $\begin{array}{r}86 \\
23 \\
12 \\
22 \\
21 \\
8\end{array}$ & $\begin{array}{r}800 \\
75 \\
22 \\
33 \\
12 \\
658\end{array}$ & $\begin{array}{r}1,248 \\
72 \\
20 \\
47 \\
26 \\
1,083\end{array}$ \\
\hline $\begin{array}{l}\text { W.N. CENTRAL } \\
\text { Minn. } \\
\text { lowa } \\
\text { Mo. } \\
\text { N. Dak. } \\
\text { S. Dak. } \\
\text { Nebr. } \\
\text { Kans. }\end{array}$ & $\begin{array}{r}321 \\
33 \\
11 \\
228 \\
2 \\
2 \\
27 \\
18\end{array}$ & $\begin{array}{r}221 \\
35 \\
20 \\
111 \\
5 \\
2 \\
26 \\
22\end{array}$ & $\begin{array}{r}272 \\
9 \\
1 \\
259 \\
- \\
- \\
3 \\
-\end{array}$ & $\begin{array}{r}627 \\
2 \\
1 \\
608 \\
- \\
1 \\
15 \\
-\end{array}$ & $\begin{array}{r}62 \\
3 \\
9 \\
33 \\
1 \\
2 \\
4 \\
10\end{array}$ & $\begin{array}{r}67 \\
17 \\
13 \\
19 \\
1 \\
4 \\
13 \\
-\end{array}$ & $\begin{array}{r}22 \\
11 \\
- \\
5 \\
- \\
- \\
4 \\
2\end{array}$ & $\begin{array}{r}18 \\
3 \\
2 \\
9 \\
1 \\
1 \\
1 \\
1\end{array}$ & $\begin{array}{r}445 \\
321 \\
48 \\
62 \\
- \\
1 \\
2 \\
11\end{array}$ & $\begin{array}{r}442 \\
344 \\
42 \\
40 \\
1 \\
2 \\
6 \\
7\end{array}$ \\
\hline $\begin{array}{l}\text { S. ATLANTIC } \\
\text { Del. } \\
\text { Md. } \\
\text { D.C. } \\
\text { Va. } \\
\text { W. Va. } \\
\text { N.C. } \\
\text { S.C. } \\
\text { Ga. } \\
\text { Fla. }\end{array}$ & $\begin{array}{r}2,019 \\
8 \\
130 \\
12 \\
186 \\
37 \\
150 \\
148 \\
746 \\
602\end{array}$ & $\begin{array}{r}1,645 \\
13 \\
123 \\
21 \\
196 \\
18 \\
216 \\
118 \\
440 \\
500\end{array}$ & $\begin{array}{r}149 \\
- \\
17 \\
- \\
9 \\
4 \\
11 \\
24 \\
5 \\
79\end{array}$ & $\begin{array}{r}199 \\
- \\
13 \\
- \\
15 \\
3 \\
26 \\
5 \\
64 \\
73\end{array}$ & $\begin{array}{r}501 \\
27 \\
129 \\
19 \\
91 \\
17 \\
37 \\
7 \\
32 \\
142\end{array}$ & $\begin{array}{r}213 \\
10 \\
50 \\
6 \\
30 \\
- \\
11 \\
10 \\
19 \\
77\end{array}$ & $\begin{array}{r}130 \\
\mathrm{~N} \\
27 \\
- \\
11 \\
6 \\
17 \\
5 \\
32 \\
32\end{array}$ & $\begin{array}{r}80 \\
N \\
19 \\
- \\
7 \\
- \\
6 \\
8 \\
14 \\
26\end{array}$ & $\begin{array}{r}1,192 \\
181 \\
602 \\
15 \\
154 \\
27 \\
121 \\
15 \\
17 \\
60\end{array}$ & $\begin{array}{r}1,367 \\
186 \\
712 \\
22 \\
204 \\
17 \\
127 \\
24 \\
2 \\
73\end{array}$ \\
\hline $\begin{array}{l}\text { E.S. CENTRAL } \\
\text { Ky. } \\
\text { Tenn. } \\
\text { Ala. } \\
\text { Miss. }\end{array}$ & $\begin{array}{r}409 \\
71 \\
193 \\
57 \\
88\end{array}$ & $\begin{array}{r}364 \\
51 \\
129 \\
96 \\
88\end{array}$ & $\begin{array}{r}78 \\
17 \\
18 \\
7 \\
36\end{array}$ & $\begin{array}{r}131 \\
4 \\
26 \\
10 \\
91\end{array}$ & $\begin{array}{r}92 \\
43 \\
33 \\
13 \\
3\end{array}$ & $\begin{array}{r}48 \\
22 \\
18 \\
8 \\
-\end{array}$ & $\begin{array}{r}31 \\
9 \\
8 \\
12 \\
2\end{array}$ & $\begin{array}{r}21 \\
4 \\
12 \\
4 \\
1\end{array}$ & $\begin{array}{r}61 \\
15 \\
17 \\
5 \\
24\end{array}$ & $\begin{array}{l}71 \\
22 \\
26 \\
11 \\
12\end{array}$ \\
\hline $\begin{array}{l}\text { W.S. CENTRAL } \\
\text { Ark. } \\
\text { La. } \\
\text { Okla. } \\
\text { Tex. }\end{array}$ & $\begin{array}{r}818 \\
59 \\
108 \\
41 \\
610\end{array}$ & $\begin{array}{r}1,000 \\
109 \\
132 \\
76 \\
683\end{array}$ & $\begin{array}{r}777 \\
3 \\
108 \\
2 \\
664\end{array}$ & $\begin{array}{r}346 \\
10 \\
94 \\
5 \\
237\end{array}$ & $\begin{array}{r}61 \\
2 \\
1 \\
7 \\
51\end{array}$ & $\begin{array}{r}33 \\
- \\
4 \\
3 \\
26\end{array}$ & $\begin{array}{r}42 \\
1 \\
3 \\
3 \\
35\end{array}$ & $\begin{array}{r}35 \\
- \\
4 \\
9 \\
22\end{array}$ & $\begin{array}{r}77 \\
- \\
6 \\
- \\
71\end{array}$ & $\begin{array}{r}138 \\
3 \\
5 \\
- \\
130\end{array}$ \\
\hline $\begin{array}{l}\text { MOUNTAIN } \\
\text { Mont. } \\
\text { Idaho } \\
\text { Wyo. } \\
\text { Colo. } \\
\text { N. Mex. } \\
\text { Ariz. } \\
\text { Utah } \\
\text { Nev. }\end{array}$ & $\begin{array}{r}582 \\
16 \\
8 \\
31 \\
79 \\
33 \\
274 \\
61 \\
80\end{array}$ & $\begin{array}{r}562 \\
9 \\
7 \\
17 \\
75 \\
145 \\
199 \\
48 \\
62\end{array}$ & $\begin{array}{r}52 \\
2 \\
1 \\
- \\
17 \\
- \\
7 \\
- \\
25\end{array}$ & $\begin{array}{r}51 \\
1 \\
1 \\
5 \\
6 \\
3 \\
4 \\
4 \\
27\end{array}$ & $\begin{array}{r}72 \\
4 \\
4 \\
2 \\
15 \\
3 \\
11 \\
23 \\
10\end{array}$ & $\begin{array}{r}48 \\
3 \\
1 \\
2 \\
8 \\
2 \\
12 \\
14 \\
6\end{array}$ & $\begin{array}{r}30 \\
2 \\
2 \\
- \\
10 \\
2 \\
10 \\
- \\
4\end{array}$ & $\begin{array}{r}29 \\
- \\
2 \\
- \\
6 \\
3 \\
14 \\
3 \\
1\end{array}$ & $\begin{array}{r}19 \\
- \\
3 \\
2 \\
4 \\
1 \\
3 \\
3 \\
3\end{array}$ & $\begin{array}{r}17 \\
- \\
4 \\
2 \\
1 \\
1 \\
3 \\
5 \\
1\end{array}$ \\
\hline $\begin{array}{l}\text { PACIFIC } \\
\text { Wash. } \\
\text { Oreg. } \\
\text { Calif. } \\
\text { Alaska } \\
\text { Hawaii }\end{array}$ & $\begin{array}{r}808 \\
71 \\
101 \\
602 \\
11 \\
23\end{array}$ & $\begin{array}{r}778 \\
69 \\
121 \\
568 \\
9 \\
11\end{array}$ & $\begin{array}{r}127 \\
15 \\
16 \\
85 \\
1 \\
10\end{array}$ & $\begin{array}{r}109 \\
24 \\
12 \\
72 \\
- \\
1\end{array}$ & $\begin{array}{r}86 \\
10 \\
N \\
76 \\
- \\
-\end{array}$ & $\begin{array}{r}63 \\
5 \\
\mathrm{~N} \\
55 \\
2 \\
1\end{array}$ & $\begin{array}{r}107 \\
6 \\
5 \\
91 \\
- \\
5\end{array}$ & $\begin{array}{r}102 \\
8 \\
9 \\
77 \\
- \\
8\end{array}$ & $\begin{array}{r}119 \\
3 \\
17 \\
96 \\
3 \\
\mathrm{~N}\end{array}$ & $\begin{array}{r}117 \\
10 \\
12 \\
92 \\
3 \\
\mathrm{~N}\end{array}$ \\
\hline $\begin{array}{l}\text { Guam } \\
\text { P.R. } \\
\text { V.I. } \\
\text { Amer. Samoa } \\
\text { C.N.M.I. }\end{array}$ & $\begin{array}{r}- \\
81 \\
- \\
-\end{array}$ & $\begin{array}{r}1 \\
175 \\
- \\
U \\
U\end{array}$ & $\begin{array}{l}- \\
- \\
- \\
\end{array}$ & $\begin{array}{l}- \\
- \\
\\
U\end{array}$ & $\begin{array}{l}- \\
- \\
\\
-\end{array}$ & $\begin{array}{l}- \\
- \\
\\
U\end{array}$ & $\begin{array}{l}- \\
- \\
\\
\end{array}$ & $\begin{array}{c}- \\
\bar{U} \\
\\
U\end{array}$ & $\begin{array}{r}\bar{N} \\
- \\
\\
-\end{array}$ & $\begin{array}{c}- \\
\bar{U} \\
\\
U\end{array}$ \\
\hline
\end{tabular}

N: Not notifiable. $\quad$ U: Unavailable.
${ }^{*}$ Incidence data for reporting years 2002 and 2003 are provisional and cumulative (year-to-date). 
TABLE II. (Continued) Provisional cases of selected notifiable diseases, United States, weeks ending December 6, 2003, and December 7, 2002 (49th Week)*

\begin{tabular}{|c|c|c|c|c|c|c|c|c|c|c|}
\hline \multirow[b]{2}{*}{ Reporting area } & \multicolumn{2}{|c|}{ Malaria } & \multicolumn{2}{|c|}{$\begin{array}{c}\text { Meningococcal } \\
\text { disease }\end{array}$} & \multicolumn{2}{|c|}{ Pertussis } & \multicolumn{2}{|c|}{ Rabies, animal } & \multicolumn{2}{|c|}{$\begin{array}{l}\text { Rocky Mountain } \\
\text { spotted fever }\end{array}$} \\
\hline & $\begin{array}{l}\text { Cum. } \\
2003\end{array}$ & $\begin{array}{l}\text { Cum. } \\
2002\end{array}$ & $\begin{array}{l}\text { Cum. } \\
2003\end{array}$ & $\begin{array}{l}\text { Cum. } \\
2002 \\
\end{array}$ & $\begin{array}{l}\text { Cum. } \\
2003\end{array}$ & $\begin{array}{l}\text { Cum. } \\
2002 \\
\end{array}$ & $\begin{array}{l}\text { Cum. } \\
2003\end{array}$ & $\begin{array}{l}\text { Cum. } \\
2002\end{array}$ & $\begin{array}{l}\text { Cum. } \\
2003\end{array}$ & $\begin{array}{l}\text { Cum. } \\
2002 \\
\end{array}$ \\
\hline UNITED STATES & 1,090 & 1,321 & 1,460 & 1,674 & 7,305 & 8,144 & 5,284 & 7,323 & 899 & 998 \\
\hline $\begin{array}{l}\text { NEW ENGLAND } \\
\text { Maine } \\
\text { N.H. } \\
\text { Vt. } \\
\text { Mass. } \\
\text { R.I. } \\
\text { Conn. }\end{array}$ & $\begin{array}{r}41 \\
3 \\
4 \\
2 \\
11 \\
2 \\
19\end{array}$ & $\begin{array}{r}78 \\
6 \\
7 \\
4 \\
33 \\
7 \\
21\end{array}$ & $\begin{array}{r}68 \\
6 \\
3 \\
3 \\
42 \\
2 \\
12\end{array}$ & $\begin{array}{r}89 \\
5 \\
14 \\
4 \\
47 \\
5 \\
14\end{array}$ & $\begin{array}{r}1,005 \\
12 \\
60 \\
64 \\
826 \\
20 \\
23\end{array}$ & $\begin{array}{r}821 \\
17 \\
43 \\
159 \\
560 \\
13 \\
29\end{array}$ & $\begin{array}{r}544 \\
64 \\
13 \\
37 \\
206 \\
57 \\
167\end{array}$ & $\begin{array}{r}880 \\
57 \\
48 \\
89 \\
294 \\
72 \\
320\end{array}$ & $\begin{array}{l}- \\
- \\
- \\
- \\
- \\
-\end{array}$ & $\begin{array}{l}7 \\
- \\
- \\
- \\
3 \\
4 \\
-\end{array}$ \\
\hline $\begin{array}{l}\text { MID. ATLANTIC } \\
\text { Upstate N.Y. } \\
\text { N.Y. City } \\
\text { N.J. } \\
\text { Pa. }\end{array}$ & $\begin{array}{r}276 \\
59 \\
134 \\
40 \\
43\end{array}$ & $\begin{array}{r}360 \\
44 \\
226 \\
42 \\
48\end{array}$ & $\begin{array}{r}181 \\
50 \\
33 \\
25 \\
73\end{array}$ & $\begin{array}{r}201 \\
50 \\
35 \\
27 \\
89\end{array}$ & $\begin{array}{r}1,007 \\
640 \\
- \\
84 \\
283\end{array}$ & $\begin{array}{r}502 \\
338 \\
22 \\
2 \\
140\end{array}$ & $\begin{array}{r}914 \\
408 \\
6 \\
62 \\
438\end{array}$ & $\begin{array}{r}1,259 \\
676 \\
21 \\
182 \\
380\end{array}$ & $\begin{array}{r}37 \\
2 \\
13 \\
11 \\
11\end{array}$ & $\begin{array}{r}59 \\
- \\
10 \\
16 \\
33\end{array}$ \\
\hline $\begin{array}{l}\text { E.N. CENTRAL } \\
\text { Ohio } \\
\text { Ind. } \\
\text { III. } \\
\text { Mich. } \\
\text { Wis. }\end{array}$ & $\begin{array}{r}84 \\
22 \\
3 \\
26 \\
23 \\
10\end{array}$ & $\begin{array}{r}157 \\
23 \\
14 \\
61 \\
45 \\
14\end{array}$ & $\begin{array}{r}204 \\
55 \\
42 \\
43 \\
43 \\
21\end{array}$ & $\begin{array}{r}255 \\
73 \\
32 \\
56 \\
45 \\
49\end{array}$ & $\begin{array}{r}670 \\
287 \\
67 \\
- \\
112 \\
204\end{array}$ & $\begin{array}{r}945 \\
414 \\
139 \\
161 \\
60 \\
171\end{array}$ & $\begin{array}{r}159 \\
53 \\
29 \\
24 \\
46 \\
7\end{array}$ & $\begin{array}{r}162 \\
39 \\
31 \\
31 \\
46 \\
15\end{array}$ & $\begin{array}{r}15 \\
9 \\
1 \\
- \\
5 \\
-\end{array}$ & $\begin{array}{r}32 \\
13 \\
4 \\
12 \\
3 \\
-\end{array}$ \\
\hline $\begin{array}{l}\text { W.N. CENTRAL } \\
\text { Minn. } \\
\text { lowa } \\
\text { Mo. } \\
\text { N. Dak. } \\
\text { S. Dak. } \\
\text { Nebr. } \\
\text { Kans. }\end{array}$ & $\begin{array}{r}48 \\
22 \\
6 \\
5 \\
1 \\
3 \\
- \\
11\end{array}$ & $\begin{array}{r}57 \\
17 \\
4 \\
15 \\
1 \\
2 \\
5 \\
13\end{array}$ & $\begin{array}{r}127 \\
26 \\
26 \\
54 \\
1 \\
1 \\
8 \\
11\end{array}$ & $\begin{array}{r}145 \\
35 \\
25 \\
49 \\
3 \\
2 \\
23 \\
8\end{array}$ & $\begin{array}{r}435 \\
141 \\
128 \\
98 \\
6 \\
5 \\
15 \\
42\end{array}$ & $\begin{array}{r}707 \\
357 \\
129 \\
139 \\
7 \\
7 \\
8 \\
60\end{array}$ & $\begin{array}{r}541 \\
38 \\
101 \\
54 \\
53 \\
67 \\
73 \\
155\end{array}$ & $\begin{array}{r}460 \\
37 \\
77 \\
50 \\
54 \\
91 \\
- \\
151\end{array}$ & $\begin{array}{r}70 \\
2 \\
2 \\
54 \\
- \\
5 \\
3 \\
4\end{array}$ & $\begin{array}{r}104 \\
- \\
3 \\
96 \\
- \\
1 \\
4 \\
-\end{array}$ \\
\hline $\begin{array}{l}\text { S. ATLANTIC } \\
\text { Del. } \\
\text { Md. } \\
\text { D.C. } \\
\text { Va. } \\
\text { W. Va. } \\
\text { N.C. } \\
\text { S.C. } \\
\text { Ga. } \\
\text { Fla. }\end{array}$ & $\begin{array}{r}306 \\
3 \\
72 \\
14 \\
38 \\
4 \\
23 \\
3 \\
64 \\
85\end{array}$ & $\begin{array}{r}309 \\
5 \\
104 \\
21 \\
32 \\
3 \\
22 \\
8 \\
49 \\
65\end{array}$ & $\begin{array}{r}250 \\
9 \\
26 \\
- \\
24 \\
6 \\
35 \\
21 \\
30 \\
99\end{array}$ & $\begin{array}{r}271 \\
7 \\
9 \\
- \\
42 \\
4 \\
32 \\
29 \\
31 \\
117\end{array}$ & $\begin{array}{r}653 \\
8 \\
82 \\
3 \\
90 \\
24 \\
126 \\
182 \\
32 \\
106\end{array}$ & $\begin{array}{r}396 \\
3 \\
62 \\
2 \\
133 \\
31 \\
43 \\
45 \\
27 \\
50\end{array}$ & $\begin{array}{r}2,374 \\
59 \\
256 \\
- \\
477 \\
81 \\
743 \\
234 \\
346 \\
178\end{array}$ & $\begin{array}{r}2,550 \\
53 \\
376 \\
- \\
562 \\
168 \\
679 \\
142 \\
395 \\
175\end{array}$ & $\begin{array}{r}565 \\
1 \\
106 \\
1 \\
30 \\
5 \\
287 \\
39 \\
82 \\
14\end{array}$ & $\begin{array}{r}475 \\
1 \\
40 \\
2 \\
40 \\
2 \\
285 \\
72 \\
19 \\
14\end{array}$ \\
\hline $\begin{array}{l}\text { E.S. CENTRAL } \\
\text { Ky. } \\
\text { Tenn. } \\
\text { Ala. } \\
\text { Miss. }\end{array}$ & $\begin{array}{r}22 \\
9 \\
7 \\
3 \\
3\end{array}$ & $\begin{array}{r}19 \\
7 \\
3 \\
4 \\
5\end{array}$ & $\begin{array}{l}80 \\
19 \\
27 \\
15 \\
19\end{array}$ & $\begin{array}{l}92 \\
15 \\
36 \\
22 \\
19\end{array}$ & $\begin{array}{r}137 \\
45 \\
70 \\
16 \\
6\end{array}$ & $\begin{array}{r}249 \\
94 \\
113 \\
33 \\
9\end{array}$ & $\begin{array}{r}171 \\
37 \\
100 \\
33 \\
1\end{array}$ & $\begin{array}{r}213 \\
26 \\
108 \\
75 \\
4\end{array}$ & $\begin{array}{r}109 \\
3 \\
65 \\
12 \\
29\end{array}$ & $\begin{array}{r}131 \\
5 \\
83 \\
16 \\
27\end{array}$ \\
\hline $\begin{array}{l}\text { W.S. CENTRAL } \\
\text { Ark. } \\
\text { La. } \\
\text { Okla. } \\
\text { Tex. }\end{array}$ & $\begin{array}{r}69 \\
4 \\
4 \\
4 \\
57\end{array}$ & $\begin{array}{r}77 \\
3 \\
4 \\
10 \\
60\end{array}$ & $\begin{array}{r}169 \\
13 \\
34 \\
17 \\
105\end{array}$ & $\begin{array}{r}206 \\
23 \\
44 \\
22 \\
117\end{array}$ & $\begin{array}{r}647 \\
37 \\
6 \\
88 \\
516\end{array}$ & $\begin{array}{r}1,589 \\
488 \\
7 \\
35 \\
1,059\end{array}$ & $\begin{array}{r}215 \\
25 \\
- \\
190 \\
-\end{array}$ & $\begin{array}{r}1,204 \\
99 \\
- \\
118 \\
987\end{array}$ & $\begin{array}{r}92 \\
39 \\
- \\
42 \\
11\end{array}$ & $\begin{array}{r}171 \\
97 \\
- \\
61 \\
13\end{array}$ \\
\hline $\begin{array}{l}\text { MOUNTAIN } \\
\text { Mont. } \\
\text { Idaho } \\
\text { Wyo. } \\
\text { Colo. } \\
\text { N. Mex. } \\
\text { Ariz. } \\
\text { Utah } \\
\text { Nev. }\end{array}$ & $\begin{array}{r}50 \\
- \\
1 \\
1 \\
22 \\
3 \\
16 \\
5 \\
2\end{array}$ & $\begin{array}{r}48 \\
2 \\
- \\
- \\
23 \\
3 \\
12 \\
5 \\
3\end{array}$ & $\begin{array}{r}74 \\
5 \\
7 \\
2 \\
22 \\
11 \\
15 \\
4 \\
8\end{array}$ & $\begin{array}{r}90 \\
2 \\
4 \\
- \\
25 \\
4 \\
30 \\
5 \\
20\end{array}$ & $\begin{array}{r}899 \\
5 \\
75 \\
125 \\
340 \\
67 \\
126 \\
126 \\
35\end{array}$ & $\begin{array}{r}1,276 \\
9 \\
143 \\
11 \\
433 \\
192 \\
339 \\
102 \\
47\end{array}$ & $\begin{array}{r}166 \\
21 \\
15 \\
6 \\
38 \\
5 \\
63 \\
14 \\
4\end{array}$ & $\begin{array}{r}306 \\
19 \\
38 \\
18 \\
59 \\
10 \\
138 \\
13 \\
11\end{array}$ & $\begin{array}{r}10 \\
1 \\
2 \\
2 \\
2 \\
1 \\
- \\
2 \\
-\end{array}$ & $\begin{array}{r}14 \\
1 \\
- \\
5 \\
2 \\
1 \\
- \\
- \\
5\end{array}$ \\
\hline $\begin{array}{l}\text { PACIFIC } \\
\text { Wash. } \\
\text { Oreg. } \\
\text { Calif. } \\
\text { Alaska } \\
\text { Hawaii }\end{array}$ & $\begin{array}{r}194 \\
26 \\
11 \\
149 \\
1 \\
7\end{array}$ & $\begin{array}{r}216 \\
24 \\
11 \\
172 \\
2 \\
7\end{array}$ & $\begin{array}{r}307 \\
37 \\
58 \\
199 \\
3 \\
10\end{array}$ & $\begin{array}{r}325 \\
62 \\
46 \\
204 \\
4 \\
9\end{array}$ & $\begin{array}{r}1,852 \\
677 \\
422 \\
735 \\
7 \\
11\end{array}$ & $\begin{array}{r}1,659 \\
437 \\
181 \\
1,007 \\
5 \\
29\end{array}$ & $\begin{array}{r}200 \\
- \\
6 \\
186 \\
8 \\
-\end{array}$ & $\begin{array}{r}289 \\
- \\
14 \\
249 \\
26 \\
-\end{array}$ & $\begin{array}{l}1 \\
- \\
- \\
1 \\
- \\
-\end{array}$ & $\begin{array}{l}5 \\
- \\
3 \\
2 \\
- \\
-\end{array}$ \\
\hline $\begin{array}{l}\text { Guam } \\
\text { P.R. } \\
\text { V.I. } \\
\text { Amer. Samoa } \\
\text { C.N.M.I. }\end{array}$ & $\begin{array}{l}\overline{1} \\
- \\
\\
-\end{array}$ & $\begin{array}{l}- \\
1 \\
- \\
U\end{array}$ & $\begin{array}{l}- \\
5 \\
- \\
\text { U }\end{array}$ & $\begin{array}{l}1 \\
7 \\
- \\
\cup \\
U\end{array}$ & $\begin{array}{l}- \\
1 \\
- \\
\end{array}$ & $\begin{array}{r}2 \\
3 \\
- \\
U \\
U\end{array}$ & $\begin{array}{r}68 \\
- \\
\end{array}$ & $\begin{array}{r}- \\
86 \\
- \\
U\end{array}$ & $\begin{array}{c}\bar{N} \\
\bar{U} \\
-\end{array}$ & $\begin{array}{l}\bar{N} \\
\bar{U} \\
U\end{array}$ \\
\hline
\end{tabular}


TABLE II. (Continued) Provisional cases of selected notifiable diseases, United States, weeks ending December 6, 2003, and December 7, 2002 (49th Week)*

\begin{tabular}{|c|c|c|c|c|c|c|c|c|c|c|}
\hline \multirow[b]{3}{*}{ Reporting area } & \multirow{2}{*}{\multicolumn{2}{|c|}{ Salmonellosis }} & \multirow{2}{*}{\multicolumn{2}{|c|}{ Shigellosis }} & \multirow{2}{*}{\multicolumn{2}{|c|}{$\begin{array}{c}\text { Streptococcal disease, } \\
\text { invasive, group A }\end{array}$}} & \multicolumn{4}{|c|}{ Streptococcus pneumoniae, invasive } \\
\hline & & & & & & & \multicolumn{2}{|c|}{$\begin{array}{l}\text { Drug resistant, } \\
\text { all ages }\end{array}$} & \multicolumn{2}{|c|}{ Age $<5$ years } \\
\hline & $\begin{array}{l}\text { Cum. } \\
2003\end{array}$ & $\begin{array}{l}\text { Cum. } \\
2002\end{array}$ & $\begin{array}{l}\text { Cum. } \\
2003 \\
\end{array}$ & $\begin{array}{l}\text { Cum. } \\
2002\end{array}$ & $\begin{array}{l}\text { Cum. } \\
2003\end{array}$ & $\begin{array}{l}\text { Cum. } \\
2002 \\
\end{array}$ & $\begin{array}{l}\text { Cum. } \\
2003 \\
\end{array}$ & $\begin{array}{l}\text { Cum. } \\
2002\end{array}$ & $\begin{array}{l}\text { Cum. } \\
2003\end{array}$ & $\begin{array}{l}\text { Cum } \\
2002 \\
\end{array}$ \\
\hline UNITED STATES & 38,592 & 41,237 & 20,602 & 20,422 & 4,919 & 4,272 & 1,933 & 2,300 & 427 & 360 \\
\hline $\begin{array}{l}\text { NEW ENGLAND } \\
\text { Maine } \\
\text { N.H. } \\
\text { Vt. } \\
\text { Mass. } \\
\text { R.I. } \\
\text { Conn. }\end{array}$ & $\begin{array}{r}1,941 \\
131 \\
100 \\
70 \\
1,139 \\
125 \\
376\end{array}$ & $\begin{array}{r}2,112 \\
138 \\
133 \\
74 \\
1,180 \\
163 \\
424\end{array}$ & $\begin{array}{r}303 \\
6 \\
5 \\
8 \\
199 \\
20 \\
65\end{array}$ & $\begin{array}{r}334 \\
10 \\
12 \\
1 \\
198 \\
17 \\
96\end{array}$ & $\begin{array}{r}350 \\
27 \\
21 \\
19 \\
166 \\
15 \\
102\end{array}$ & $\begin{array}{r}305 \\
20 \\
35 \\
10 \\
103 \\
15 \\
122\end{array}$ & $\begin{array}{r}40 \\
- \\
- \\
6 \\
N \\
10 \\
24\end{array}$ & $\begin{array}{r}111 \\
- \\
- \\
5 \\
N \\
13 \\
93\end{array}$ & $\begin{array}{r}9 \\
- \\
N \\
5 \\
N \\
4 \\
\text { U }\end{array}$ & $\begin{array}{r}3 \\
- \\
N \\
2 \\
N \\
1 \\
U\end{array}$ \\
\hline $\begin{array}{l}\text { MID. ATLANTIC } \\
\text { Upstate N.Y. } \\
\text { N.Y. City } \\
\text { N.J. } \\
\text { Pa. }\end{array}$ & $\begin{array}{r}4,313 \\
1,096 \\
1,208 \\
539 \\
1,470\end{array}$ & $\begin{array}{l}5,570 \\
1,469 \\
1,340 \\
1,023 \\
1,738\end{array}$ & $\begin{array}{r}2,169 \\
545 \\
378 \\
272 \\
974\end{array}$ & $\begin{array}{r}1,740 \\
321 \\
480 \\
599 \\
340\end{array}$ & $\begin{array}{l}860 \\
342 \\
122 \\
143 \\
253\end{array}$ & $\begin{array}{l}672 \\
266 \\
150 \\
142 \\
114\end{array}$ & $\begin{array}{r}124 \\
69 \\
U \\
N \\
55\end{array}$ & $\begin{array}{r}113 \\
84 \\
U \\
N \\
29\end{array}$ & $\begin{array}{r}93 \\
71 \\
U \\
N \\
22\end{array}$ & $\begin{array}{r}83 \\
69 \\
U \\
N \\
14\end{array}$ \\
\hline $\begin{array}{l}\text { E.N. CENTRAL } \\
\text { Ohio } \\
\text { Ind. } \\
\text { III. } \\
\text { Mich. } \\
\text { Wis. }\end{array}$ & $\begin{array}{r}5,052 \\
1,282 \\
565 \\
1,604 \\
751 \\
850\end{array}$ & $\begin{array}{r}5,322 \\
1,335 \\
537 \\
1,737 \\
841 \\
872\end{array}$ & $\begin{array}{r}1,632 \\
287 \\
178 \\
820 \\
232 \\
115\end{array}$ & $\begin{array}{r}2,125 \\
618 \\
108 \\
1,035 \\
181 \\
183\end{array}$ & $\begin{array}{r}998 \\
280 \\
105 \\
182 \\
346 \\
85\end{array}$ & $\begin{array}{r}926 \\
196 \\
49 \\
271 \\
289 \\
121\end{array}$ & $\begin{array}{r}413 \\
269 \\
144 \\
- \\
\mathrm{N} \\
\mathrm{N}\end{array}$ & $\begin{array}{r}239 \\
81 \\
156 \\
2 \\
\mathrm{~N} \\
\mathrm{~N}\end{array}$ & $\begin{array}{r}173 \\
95 \\
49 \\
- \\
N \\
29\end{array}$ & $\begin{array}{r}149 \\
27 \\
64 \\
- \\
\mathrm{N} \\
58\end{array}$ \\
\hline $\begin{array}{l}\text { W.N. CENTRAL } \\
\text { Minn. } \\
\text { lowa } \\
\text { Mo. } \\
\text { N. Dak. } \\
\text { S. Dak. } \\
\text { Nebr. } \\
\text { Kans. }\end{array}$ & $\begin{array}{r}2,417 \\
543 \\
369 \\
944 \\
37 \\
115 \\
135 \\
274\end{array}$ & $\begin{array}{r}2,516 \\
555 \\
484 \\
803 \\
41 \\
109 \\
181 \\
343\end{array}$ & $\begin{array}{r}784 \\
100 \\
86 \\
367 \\
6 \\
16 \\
100 \\
109\end{array}$ & $\begin{array}{r}1,035 \\
210 \\
120 \\
190 \\
18 \\
157 \\
249 \\
91\end{array}$ & $\begin{array}{r}313 \\
155 \\
\mathrm{~N} \\
68 \\
15 \\
21 \\
25 \\
29\end{array}$ & $\begin{array}{r}234 \\
114 \\
\mathrm{~N} \\
42 \\
3 \\
14 \\
14 \\
24 \\
37\end{array}$ & $\begin{array}{r}155 \\
- \\
\mathrm{N} \\
14 \\
3 \\
1 \\
- \\
137\end{array}$ & $\begin{array}{r}430 \\
292 \\
\mathrm{~N} \\
5 \\
1 \\
1 \\
26 \\
105\end{array}$ & $\begin{array}{r}61 \\
51 \\
\mathrm{~N} \\
3 \\
7 \\
- \\
\mathrm{N} \\
\mathrm{N}\end{array}$ & $\begin{array}{r}59 \\
55 \\
\mathrm{~N} \\
1 \\
3 \\
- \\
\mathrm{N} \\
\mathrm{N}\end{array}$ \\
\hline $\begin{array}{l}\text { S. ATLANTIC } \\
\text { Del. } \\
\text { Md. } \\
\text { D.C. } \\
\text { Va. } \\
\text { W. Va. } \\
\text { N.C. } \\
\text { S.C. } \\
\text { Ga. } \\
\text { Fla. }\end{array}$ & $\begin{array}{r}10,586 \\
89 \\
819 \\
50 \\
1,041 \\
123 \\
1,301 \\
775 \\
2,138 \\
4,250\end{array}$ & $\begin{array}{r}10,856 \\
100 \\
889 \\
76 \\
1,160 \\
146 \\
1,480 \\
821 \\
1,881 \\
4,303\end{array}$ & $\begin{array}{r}6,860 \\
154 \\
556 \\
71 \\
418 \\
- \\
944 \\
507 \\
1,572 \\
2,638\end{array}$ & $\begin{array}{r}6,853 \\
356 \\
1,146 \\
60 \\
922 \\
12 \\
422 \\
128 \\
1,671 \\
2,136\end{array}$ & $\begin{array}{r}853 \\
6 \\
258 \\
14 \\
94 \\
33 \\
102 \\
36 \\
111 \\
199\end{array}$ & $\begin{array}{r}688 \\
2 \\
115 \\
9 \\
73 \\
19 \\
113 \\
38 \\
123 \\
196\end{array}$ & $\begin{array}{r}978 \\
1 \\
- \\
2 \\
\mathrm{~N} \\
70 \\
\mathrm{~N} \\
137 \\
227 \\
541\end{array}$ & $\begin{array}{r}1,058 \\
3 \\
- \\
- \\
N \\
43 \\
N \\
188 \\
266 \\
558\end{array}$ & $\begin{array}{r}18 \\
\mathrm{~N} \\
- \\
7 \\
\mathrm{~N} \\
11 \\
\mathrm{U} \\
\mathrm{N} \\
\mathrm{N} \\
\mathrm{N}\end{array}$ & $\begin{array}{r}35 \\
N \\
25 \\
3 \\
N \\
7 \\
\text { U } \\
N \\
N \\
N\end{array}$ \\
\hline $\begin{array}{l}\text { E.S. CENTRAL } \\
\text { Ky. } \\
\text { Tenn. } \\
\text { Ala. } \\
\text { Miss. }\end{array}$ & $\begin{array}{r}2,526 \\
372 \\
718 \\
498 \\
938\end{array}$ & $\begin{array}{r}3,138 \\
376 \\
797 \\
826 \\
1,139\end{array}$ & $\begin{array}{l}887 \\
125 \\
356 \\
242 \\
164\end{array}$ & $\begin{array}{r}1,456 \\
188 \\
144 \\
787 \\
337\end{array}$ & $\begin{array}{r}195 \\
43 \\
152 \\
- \\
-\end{array}$ & $\begin{array}{r}110 \\
19 \\
91 \\
- \\
-\end{array}$ & $\begin{array}{r}137 \\
18 \\
119 \\
- \\
-\end{array}$ & $\begin{array}{r}124 \\
17 \\
107 \\
- \\
-\end{array}$ & $\begin{array}{r}- \\
N \\
N \\
N \\
-\end{array}$ & $\begin{array}{r}- \\
N \\
N \\
N \\
-\end{array}$ \\
\hline $\begin{array}{l}\text { W.S. CENTRAL } \\
\text { Ark. } \\
\text { La. } \\
\text { Okla. } \\
\text { Tex. }\end{array}$ & $\begin{array}{r}4,580 \\
760 \\
522 \\
448 \\
2,850\end{array}$ & $\begin{array}{r}4,512 \\
1,036 \\
778 \\
489 \\
2,209\end{array}$ & $\begin{array}{r}4,335 \\
95 \\
297 \\
825 \\
3,118\end{array}$ & $\begin{array}{r}3,110 \\
192 \\
480 \\
562 \\
1,876\end{array}$ & $\begin{array}{r}333 \\
5 \\
1 \\
88 \\
239\end{array}$ & $\begin{array}{r}278 \\
8 \\
1 \\
43 \\
226\end{array}$ & $\begin{array}{r}58 \\
8 \\
50 \\
N \\
N\end{array}$ & $\begin{array}{r}177 \\
9 \\
168 \\
N \\
N\end{array}$ & $\begin{array}{r}68 \\
- \\
8 \\
38 \\
22\end{array}$ & $\begin{array}{r}27 \\
- \\
9 \\
6 \\
12\end{array}$ \\
\hline $\begin{array}{l}\text { MOUNTAIN } \\
\text { Mont. } \\
\text { Idaho } \\
\text { Wyo. } \\
\text { Colo. } \\
\text { N. Mex. } \\
\text { Ariz. } \\
\text { Utah } \\
\text { Nev. }\end{array}$ & $\begin{array}{r}2,174 \\
108 \\
170 \\
74 \\
443 \\
255 \\
736 \\
216 \\
172\end{array}$ & $\begin{array}{r}2,118 \\
87 \\
147 \\
106 \\
575 \\
304 \\
515 \\
176 \\
208\end{array}$ & $\begin{array}{r}1,206 \\
2 \\
33 \\
8 \\
277 \\
240 \\
530 \\
50 \\
66\end{array}$ & $\begin{array}{r}885 \\
4 \\
15 \\
8 \\
205 \\
220 \\
352 \\
32 \\
49\end{array}$ & $\begin{array}{r}435 \\
2 \\
19 \\
2 \\
126 \\
110 \\
163 \\
11 \\
2\end{array}$ & $\begin{array}{r}526 \\
- \\
11 \\
7 \\
117 \\
105 \\
256 \\
30 \\
-\end{array}$ & $\begin{array}{r}25 \\
- \\
\mathrm{N} \\
7 \\
- \\
18 \\
- \\
- \\
-\end{array}$ & $\begin{array}{r}48 \\
- \\
N \\
13 \\
- \\
34 \\
- \\
- \\
1\end{array}$ & $\begin{array}{r}5 \\
- \\
\mathrm{N} \\
- \\
- \\
- \\
\mathrm{N} \\
5 \\
-\end{array}$ & $\begin{array}{c}4 \\
- \\
\mathrm{N} \\
- \\
- \\
- \\
\mathrm{N} \\
4 \\
-\end{array}$ \\
\hline $\begin{array}{l}\text { PACIFIC } \\
\text { Wash. } \\
\text { Oreg. } \\
\text { Calif. } \\
\text { Alaska } \\
\text { Hawaii }\end{array}$ & $\begin{array}{r}5,003 \\
547 \\
399 \\
3,746 \\
95 \\
216\end{array}$ & $\begin{array}{r}5,093 \\
494 \\
327 \\
3,936 \\
79 \\
257\end{array}$ & $\begin{array}{r}2,426 \\
150 \\
209 \\
2,014 \\
10 \\
43\end{array}$ & $\begin{array}{r}2,884 \\
170 \\
107 \\
2,534 \\
5 \\
68\end{array}$ & $\begin{array}{r}582 \\
70 \\
\mathrm{~N} \\
387 \\
- \\
125\end{array}$ & $\begin{array}{r}533 \\
60 \\
\mathrm{~N} \\
372 \\
- \\
101\end{array}$ & $\begin{array}{l}3 \\
- \\
N \\
N \\
- \\
3\end{array}$ & $\begin{array}{l}- \\
- \\
N \\
N \\
-\end{array}$ & $\begin{array}{l}- \\
N \\
N \\
N \\
N \\
-\end{array}$ & $\begin{array}{l}- \\
N \\
N \\
N \\
N \\
-\end{array}$ \\
\hline $\begin{array}{l}\text { Guam } \\
\text { P.R. } \\
\text { V.I. } \\
\text { Amer. Samoa } \\
\text { C.N.M.I. }\end{array}$ & $\begin{array}{r}- \\
325 \\
- \\
-\end{array}$ & $\begin{array}{r}40 \\
526 \\
- \\
U\end{array}$ & $\begin{array}{l}- \\
8 \\
- \\
\\
-\end{array}$ & $\begin{array}{r}36 \\
30 \\
- \\
U\end{array}$ & $\begin{array}{c}- \\
\text { N } \\
-\end{array}$ & $\begin{array}{r}\bar{N} \\
- \\
U \\
U\end{array}$ & $\begin{array}{c}- \\
\mathrm{N} \\
- \\
\mathrm{U} \\
-\end{array}$ & $\begin{array}{c}4 \\
\mathrm{~N} \\
- \\
\mathrm{U} \\
\mathrm{U}\end{array}$ & $\begin{array}{c}- \\
\mathrm{N} \\
- \\
\mathrm{U} \\
-\end{array}$ & $\begin{array}{l}\bar{N} \\
\bar{U} \\
U\end{array}$ \\
\hline
\end{tabular}


TABLE II. (Continued) Provisional cases of selected notifiable diseases, United States, weeks ending December 6, 2003, and December 7, 2002 (49th Week)*

\begin{tabular}{|c|c|c|c|c|c|c|c|c|c|}
\hline \multirow[b]{3}{*}{ Reporting area } & \multicolumn{4}{|c|}{ Syphilis } & \multirow{2}{*}{\multicolumn{2}{|c|}{ Tuberculosis }} & \multirow{2}{*}{\multicolumn{2}{|c|}{ Typhoid fever }} & \multirow{3}{*}{$\begin{array}{c}\begin{array}{c}\text { Varicella } \\
\text { (Chickenpox) }\end{array} \\
\text { Cum. } \\
2003 \\
\end{array}$} \\
\hline & \multicolumn{2}{|c|}{ Primary \& secondary } & \multicolumn{2}{|c|}{ Congenital } & & & & & \\
\hline & $\begin{array}{l}\text { Cum. } \\
2003\end{array}$ & $\begin{array}{l}\text { Cum. } \\
2002 \\
\end{array}$ & $\begin{array}{l}\text { Cum. } \\
2003\end{array}$ & $\begin{array}{l}\text { Cum. } \\
2002 \\
\end{array}$ & $\begin{array}{l}\text { Cum. } \\
2003\end{array}$ & $\begin{array}{l}\text { Cum. } \\
2002\end{array}$ & $\begin{array}{l}\text { Cum. } \\
2003\end{array}$ & $\begin{array}{l}\text { Cum. } \\
2002 \\
\end{array}$ & \\
\hline UNITED STATES & 6,318 & 6,352 & 346 & 406 & 10,517 & 12,079 & 297 & 306 & 12,261 \\
\hline $\begin{array}{l}\text { NEW ENGLAND } \\
\text { Maine } \\
\text { N.H. } \\
\text { Vt. } \\
\text { Mass. } \\
\text { R.I. } \\
\text { Conn. }\end{array}$ & $\begin{array}{r}192 \\
7 \\
14 \\
1 \\
128 \\
18 \\
24\end{array}$ & $\begin{array}{r}140 \\
2 \\
7 \\
2 \\
93 \\
9 \\
27\end{array}$ & $\begin{array}{l}1 \\
1 \\
- \\
- \\
- \\
- \\
-\end{array}$ & $\begin{array}{l}1 \\
- \\
- \\
- \\
1 \\
- \\
-\end{array}$ & $\begin{array}{r}295 \\
5 \\
7 \\
7 \\
194 \\
32 \\
50\end{array}$ & $\begin{array}{r}405 \\
20 \\
17 \\
7 \\
219 \\
48 \\
94\end{array}$ & $\begin{array}{r}23 \\
- \\
2 \\
- \\
12 \\
2 \\
7\end{array}$ & $\begin{array}{l}13 \\
- \\
- \\
- \\
7 \\
- \\
6\end{array}$ & $\begin{array}{r}1,722 \\
776 \\
- \\
790 \\
151 \\
5 \\
-\end{array}$ \\
\hline $\begin{array}{l}\text { MID. ATLANTIC } \\
\text { Upstate N.Y. } \\
\text { N.Y. City } \\
\text { N.J. } \\
\text { Pa. }\end{array}$ & $\begin{array}{r}809 \\
43 \\
454 \\
161 \\
151\end{array}$ & $\begin{array}{r}691 \\
31 \\
407 \\
154 \\
99\end{array}$ & $\begin{array}{r}61 \\
15 \\
31 \\
15 \\
-\end{array}$ & $\begin{array}{r}65 \\
4 \\
25 \\
35 \\
1\end{array}$ & $\begin{array}{r}2,027 \\
266 \\
1,066 \\
400 \\
295\end{array}$ & $\begin{array}{r}2,073 \\
294 \\
1,002 \\
468 \\
309\end{array}$ & $\begin{array}{r}54 \\
11 \\
21 \\
16 \\
6\end{array}$ & $\begin{array}{r}76 \\
9 \\
41 \\
18 \\
8\end{array}$ & $\begin{array}{r}37 \\
\mathrm{~N} \\
- \\
- \\
37\end{array}$ \\
\hline $\begin{array}{l}\text { E.N. CENTRAL } \\
\text { Ohio } \\
\text { Ind. } \\
\text { III. } \\
\text { Mich. } \\
\text { Wis. }\end{array}$ & $\begin{array}{r}800 \\
192 \\
47 \\
314 \\
235 \\
12\end{array}$ & $\begin{array}{r}1,146 \\
152 \\
60 \\
448 \\
460 \\
26\end{array}$ & $\begin{array}{r}67 \\
3 \\
11 \\
20 \\
33 \\
-\end{array}$ & $\begin{array}{r}64 \\
3 \\
3 \\
37 \\
21 \\
-\end{array}$ & $\begin{array}{r}1,067 \\
186 \\
123 \\
505 \\
201 \\
52\end{array}$ & $\begin{array}{r}1,241 \\
213 \\
117 \\
601 \\
248 \\
62\end{array}$ & $\begin{array}{r}23 \\
2 \\
4 \\
7 \\
10 \\
-\end{array}$ & $\begin{array}{r}33 \\
6 \\
2 \\
17 \\
4 \\
4\end{array}$ & $\begin{array}{r}5,591 \\
1,118 \\
- \\
3,624 \\
849\end{array}$ \\
\hline $\begin{array}{l}\text { W.N. CENTRAL } \\
\text { Minn. } \\
\text { lowa } \\
\text { Mo. } \\
\text { N. Dak. } \\
\text { S. Dak. } \\
\text { Nebr. } \\
\text { Kans. }\end{array}$ & $\begin{array}{r}137 \\
41 \\
7 \\
51 \\
2 \\
2 \\
11 \\
23\end{array}$ & $\begin{array}{r}119 \\
57 \\
4 \\
32 \\
- \\
- \\
6 \\
20\end{array}$ & $\begin{array}{l}4 \\
- \\
- \\
4 \\
- \\
- \\
- \\
-\end{array}$ & $\begin{array}{l}2 \\
1 \\
- \\
1 \\
- \\
- \\
- \\
-\end{array}$ & $\begin{array}{r}440 \\
182 \\
25 \\
103 \\
4 \\
16 \\
18 \\
92\end{array}$ & $\begin{array}{r}495 \\
211 \\
31 \\
126 \\
6 \\
11 \\
25 \\
85\end{array}$ & $\begin{array}{l}4 \\
- \\
2 \\
1 \\
- \\
- \\
1 \\
-\end{array}$ & $\begin{array}{r}10 \\
4 \\
- \\
2 \\
- \\
- \\
4 \\
-\end{array}$ & $\begin{array}{r}73 \\
N \\
N \\
- \\
73 \\
- \\
- \\
-\end{array}$ \\
\hline $\begin{array}{l}\text { S. ATLANTIC } \\
\text { Del. } \\
\text { Md. } \\
\text { D.C. } \\
\text { Va. } \\
\text { W. Va. } \\
\text { N.C. } \\
\text { S.C. } \\
\text { Ga. } \\
\text { Fla. }\end{array}$ & $\begin{array}{r}1,681 \\
6 \\
284 \\
52 \\
70 \\
2 \\
143 \\
93 \\
442 \\
589\end{array}$ & $\begin{array}{r}1,644 \\
11 \\
205 \\
53 \\
65 \\
2 \\
267 \\
127 \\
357 \\
557\end{array}$ & $\begin{array}{r}67 \\
- \\
10 \\
- \\
1 \\
- \\
19 \\
7 \\
11 \\
19\end{array}$ & $\begin{array}{r}89 \\
- \\
15 \\
1 \\
1 \\
- \\
19 \\
13 \\
13 \\
27\end{array}$ & $\begin{array}{r}2,116 \\
23 \\
220 \\
- \\
246 \\
20 \\
315 \\
161 \\
340 \\
791\end{array}$ & $\begin{array}{r}2,452 \\
20 \\
267 \\
- \\
249 \\
28 \\
333 \\
146 \\
501 \\
908\end{array}$ & $\begin{array}{r}51 \\
- \\
8 \\
- \\
12 \\
- \\
9 \\
- \\
8 \\
14\end{array}$ & $\begin{array}{r}41 \\
- \\
8 \\
- \\
7 \\
- \\
2 \\
- \\
5 \\
19\end{array}$ & $\begin{array}{r}2,010 \\
28 \\
- \\
28 \\
494 \\
1,204 \\
\mathrm{~N} \\
256 \\
- \\
\mathrm{N}\end{array}$ \\
\hline $\begin{array}{l}\text { E.S. CENTRAL } \\
\text { Ky. } \\
\text { Tenn. } \\
\text { Ala. } \\
\text { Miss. }\end{array}$ & $\begin{array}{r}302 \\
32 \\
128 \\
110 \\
32\end{array}$ & $\begin{array}{r}437 \\
86 \\
160 \\
146 \\
45\end{array}$ & $\begin{array}{r}11 \\
1 \\
3 \\
5 \\
2\end{array}$ & $\begin{array}{r}30 \\
3 \\
11 \\
10 \\
6\end{array}$ & $\begin{array}{r}628 \\
122 \\
198 \\
220 \\
88\end{array}$ & $\begin{array}{l}704 \\
124 \\
270 \\
192 \\
118\end{array}$ & $\begin{array}{l}6 \\
1 \\
3 \\
2 \\
-\end{array}$ & $\begin{array}{l}4 \\
4 \\
- \\
- \\
-\end{array}$ & $\begin{array}{l}2 \\
N \\
N \\
- \\
2\end{array}$ \\
\hline $\begin{array}{l}\text { W.S. CENTRAL } \\
\text { Ark. } \\
\text { La. } \\
\text { Okla. } \\
\text { Tex. }\end{array}$ & $\begin{array}{r}878 \\
49 \\
156 \\
61 \\
612\end{array}$ & $\begin{array}{r}793 \\
32 \\
146 \\
64 \\
551\end{array}$ & $\begin{array}{r}67 \\
2 \\
- \\
1 \\
64\end{array}$ & $\begin{array}{r}84 \\
11 \\
- \\
2 \\
71\end{array}$ & $\begin{array}{r}1,403 \\
88 \\
- \\
137 \\
1,178\end{array}$ & $\begin{array}{r}1,737 \\
118 \\
- \\
159 \\
1,460\end{array}$ & $\begin{array}{r}32 \\
- \\
- \\
1 \\
31\end{array}$ & $\begin{array}{r}30 \\
- \\
- \\
2 \\
28\end{array}$ & $\begin{array}{r}2,169 \\
- \\
13 \\
N \\
2,156\end{array}$ \\
\hline $\begin{array}{l}\text { MOUNTAIN } \\
\text { Mont. } \\
\text { Idaho } \\
\text { Wyo. } \\
\text { Colo. } \\
\text { N. Mex. } \\
\text { Ariz. } \\
\text { Utah } \\
\text { Nev. }\end{array}$ & $\begin{array}{r}277 \\
- \\
12 \\
- \\
24 \\
57 \\
167 \\
7 \\
10\end{array}$ & $\begin{array}{r}313 \\
- \\
8 \\
- \\
64 \\
36 \\
184 \\
6 \\
15\end{array}$ & $\begin{array}{r}22 \\
- \\
- \\
- \\
3 \\
1 \\
18 \\
- \\
-\end{array}$ & $\begin{array}{r}16 \\
- \\
- \\
- \\
2 \\
- \\
14 \\
- \\
-\end{array}$ & $\begin{array}{r}344 \\
5 \\
8 \\
4 \\
64 \\
6 \\
200 \\
35 \\
22\end{array}$ & $\begin{array}{r}411 \\
6 \\
14 \\
3 \\
92 \\
34 \\
217 \\
31 \\
14\end{array}$ & $\begin{array}{l}6 \\
- \\
1 \\
- \\
3 \\
- \\
2 \\
- \\
-\end{array}$ & $\begin{array}{l}9 \\
- \\
- \\
- \\
4 \\
1 \\
- \\
2 \\
2\end{array}$ & $\begin{array}{r}657 \\
N \\
N \\
86 \\
- \\
3 \\
4 \\
564 \\
-\end{array}$ \\
\hline $\begin{array}{l}\text { PACIFIC } \\
\text { Wash. } \\
\text { Oreg. } \\
\text { Calif. } \\
\text { Alaska } \\
\text { Hawaii }\end{array}$ & $\begin{array}{r}1,242 \\
75 \\
42 \\
1,123 \\
- \\
2\end{array}$ & $\begin{array}{r}1,069 \\
58 \\
23 \\
980 \\
- \\
8\end{array}$ & $\begin{array}{r}46 \\
- \\
- \\
46 \\
- \\
-\end{array}$ & $\begin{array}{r}55 \\
2 \\
- \\
52 \\
- \\
1\end{array}$ & $\begin{array}{r}2,197 \\
224 \\
95 \\
1,757 \\
53 \\
68\end{array}$ & $\begin{array}{r}2,561 \\
228 \\
104 \\
2,048 \\
46 \\
135\end{array}$ & $\begin{array}{r}98 \\
3 \\
5 \\
89 \\
- \\
1\end{array}$ & $\begin{array}{r}90 \\
6 \\
2 \\
77 \\
- \\
5\end{array}$ & $\begin{array}{l}- \\
- \\
- \\
- \\
-\end{array}$ \\
\hline $\begin{array}{l}\text { Guam } \\
\text { P.R. } \\
\text { V.I. } \\
\text { Amer. Samoa } \\
\text { C.N.M.I. }\end{array}$ & $\begin{array}{r}- \\
183 \\
1 \\
U \\
-\end{array}$ & $\begin{array}{r}6 \\
274 \\
1 \\
\cup \\
U\end{array}$ & $\begin{array}{l}- \\
1 \\
- \\
\end{array}$ & $\begin{array}{r}- \\
23 \\
\text { U } \\
U\end{array}$ & $\begin{array}{r}- \\
86 \\
- \\
\end{array}$ & $\begin{array}{r}64 \\
104 \\
- \\
U \\
U\end{array}$ & $\begin{array}{l}- \\
- \\
\bar{U} \\
-\end{array}$ & $\begin{array}{l}- \\
- \\
\text { U }\end{array}$ & $\begin{array}{r}402 \\
- \\
\\
-\end{array}$ \\
\hline
\end{tabular}

$\mathrm{N}$ : Not notifiable. 
TABLE III. Deaths in 122 U.S. cities, ${ }^{*}$ week ending December 6, 2003 (49th Week)

\begin{tabular}{|c|c|c|c|c|c|c|c|c|c|c|c|c|c|c|c|}
\hline \multirow[b]{2}{*}{ Reporting Area } & \multicolumn{6}{|c|}{ All causes, by age (years) } & \multirow[b]{2}{*}{$\begin{array}{l}\text { P\&I }{ }^{\dagger} \\
\text { Total }\end{array}$} & \multirow[b]{2}{*}{ Reporting Area } & \multicolumn{6}{|c|}{ All causes, by age (years) } & \multirow[b]{2}{*}{$\begin{array}{l}\text { P\&I } \\
\text { Total }\end{array}$} \\
\hline & $\begin{array}{c}\text { All } \\
\text { Ages }\end{array}$ & $\geq 65$ & $45-64$ & $25-44$ & $1-24$ & $<1$ & & & $\begin{array}{c}\text { All } \\
\text { Ages }\end{array}$ & $\geq 65$ & $45-64$ & $25-44$ & $1-24$ & $<1$ & \\
\hline NEW ENGLAND & 532 & 372 & 106 & 38 & 10 & 6 & 60 & S. ATLANTIC & 1,376 & 823 & 330 & 139 & 42 & 42 & 80 \\
\hline Boston, Mass. & 133 & 85 & 29 & 12 & 5 & 2 & 8 & Atlanta, Ga. & 124 & 73 & 28 & 20 & 2 & 1 & 6 \\
\hline Bridgeport, Conn. & 4 & 2 & 2 & - & - & - & - & Baltimore, Md. & 173 & 92 & 46 & 20 & 9 & 6 & 12 \\
\hline Cambridge, Mass. & 31 & 27 & 3 & 1 & - & - & 4 & Charlotte, N.C. & 116 & 79 & 22 & 9 & 2 & 4 & 16 \\
\hline Fall River, Mass. & 28 & 24 & 2 & 2 & - & - & 5 & Jacksonville, Fla. & 154 & 92 & 38 & 13 & 3 & 8 & 2 \\
\hline Hartford, Conn. & 52 & 26 & 20 & 4 & 1 & 1 & 13 & Miami, Fla. & 117 & 68 & 35 & 10 & 3 & 1 & 4 \\
\hline Lowell, Mass. & 21 & 18 & 2 & 1 & - & - & 3 & Norfolk, Va. & 63 & 41 & 12 & 7 & 2 & 1 & 4 \\
\hline Lynn, Mass. & 14 & 8 & 4 & 1 & 1 & - & - & Richmond, Va. & 73 & 40 & 22 & 8 & 1 & 2 & 5 \\
\hline New Bedford, Mass. & 35 & 23 & 5 & 6 & 1 & - & 3 & Savannah, Ga. & 59 & 38 & 15 & 3 & 2 & 1 & 3 \\
\hline New Haven, Conn. & U & U & U & U & $U$ & $U$ & $U$ & St. Petersburg, Fla. & 43 & 27 & 12 & 2 & 1 & 1 & 3 \\
\hline Providence, R.I. & 72 & 50 & 12 & 6 & 2 & 2 & 7 & Tampa, Fla. & 245 & 161 & 48 & 24 & 6 & 6 & 17 \\
\hline Somerville, Mass. & 6 & 5 & 1 & - & - & - & - & Washington, D.C. & 196 & 101 & 51 & 22 & 11 & 11 & 6 \\
\hline Springfield, Mass. & 45 & 34 & 8 & 3 & - & - & 6 & Wilmington, Del. & 13 & 11 & 1 & 1 & - & - & 2 \\
\hline Waterbury, Conn. & 33 & 25 & 7 & 1 & - & - & 4 & & 880 & 582 & 200 & 54 & 21 & 22 & 67 \\
\hline Worcester, Mass. & 58 & 45 & 11 & 1 & - & 1 & 7 & Birmingham, Ala. & $\begin{array}{l}880 \\
162\end{array}$ & $\begin{array}{l}582 \\
107\end{array}$ & 39 & $\begin{array}{r}54 \\
6\end{array}$ & 5 & 4 & 25 \\
\hline MID. ATLANTIC & 2,695 & 1,876 & 550 & 173 & 49 & 40 & 157 & Chattanooga, Tenn. & 74 & 47 & 18 & 9 & - & - & 4 \\
\hline Albany, N.Y. & 55 & 41 & 9 & 4 & 1 & - & 4 & Knoxville, Tenn. & 122 & 85 & 25 & 4 & 4 & 4 & - \\
\hline Allentown, $\mathrm{Pa}$. & 20 & 18 & 2 & - & - & - & 2 & Lexington, Ky. & 77 & 57 & 11 & 5 & 3 & 1 & 8 \\
\hline Buffalo, N.Y. & 93 & 65 & 19 & 6 & 2 & 1 & 11 & Memphis, Tenn. & 137 & 87 & 34 & 8 & 2 & 6 & 6 \\
\hline Camden, N.J. & 33 & 22 & 6 & 3 & 2 & - & - & Mobile, Ala. & 105 & 69 & 27 & 8 & - & 1 & 5 \\
\hline Elizabeth, N.J. & 27 & 19 & 7 & 1 & - & - & 1 & Montgomery, Ala. & 51 & 36 & 8 & 4 & 1 & 2 & 10 \\
\hline Erie, $\mathrm{Pa}$. & 47 & 34 & 10 & 3 & - & - & 2 & Nashville, Tenn. & 152 & 94 & 38 & 10 & 6 & 4 & 9 \\
\hline Jersey City, N.J. & 35 & 19 & 14 & 2 & - & - & - & WS CENTRAL & 1.585 & 1.002 & 361 & 132 & 39 & 51 & 108 \\
\hline New York City, N.Y. & 1,515 & 1,064 & 303 & 94 & 31 & 16 & 67 & $\begin{array}{l}\text { W.S. CENIIRAL } \\
\text { Austin, Tex. }\end{array}$ & $\begin{array}{l}1,005 \\
103\end{array}$ & 79 & $\begin{array}{r}301 \\
11\end{array}$ & 7 & $\begin{array}{r}39 \\
4\end{array}$ & 2 & $\begin{array}{r}108 \\
9\end{array}$ \\
\hline Newark, N.J. & 72 & 29 & 24 & 14 & - & 5 & 5 & & 39 & 25 & 13 & 1 & - & - & $\begin{array}{l}y \\
-\end{array}$ \\
\hline Paterson, N.J. & 25 & 14 & 8 & 3 & - & - & - & $\begin{array}{l}\text { Baton Rouge, La. } \\
\text { Corpus Christi. Tex. }\end{array}$ & 68 & 42 & 12 & 9 & 2 & 3 & 6 \\
\hline Philadelphia, $\mathrm{Pa}$. & 225 & 134 & 57 & 19 & 8 & 7 & 11 & $\begin{array}{l}\text { Corpus Christl, Iex. } \\
\text { Dallas. Tex. }\end{array}$ & 233 & $\begin{array}{r}42 \\
133\end{array}$ & 58 & 26 & $\begin{array}{l}2 \\
8\end{array}$ & 8 & $\begin{array}{l}6 \\
9\end{array}$ \\
\hline Pittsburgh, $\mathrm{Pa} .^{\S}$ & 36 & 21 & 6 & 5 & - & 4 & - & $\begin{array}{l}\text { Dallas, lex. } \\
\text { EI Paso. Tex }\end{array}$ & $\begin{array}{l}230 \\
112\end{array}$ & $\begin{array}{r}135 \\
75\end{array}$ & $\begin{array}{l}58 \\
26\end{array}$ & $\begin{array}{r}20 \\
6\end{array}$ & $\begin{array}{l}0 \\
2\end{array}$ & $\begin{array}{l}8 \\
3\end{array}$ & $\begin{array}{l}9 \\
2\end{array}$ \\
\hline Reading, $\mathrm{Pa}$. & 27 & 24 & 3 & - & - & - & 7 & El Paso, lex. & 121 & $\begin{array}{l}15 \\
74\end{array}$ & $\begin{array}{l}20 \\
32\end{array}$ & $\begin{array}{l}0 \\
9\end{array}$ & $\begin{array}{l}2 \\
3\end{array}$ & $\begin{array}{l}3 \\
3\end{array}$ & $\begin{array}{l}2 \\
5\end{array}$ \\
\hline Rochester, N.Y. & 187 & 139 & 33 & 6 & 4 & 5 & 22 & Ft. Worth, Iex. & 418 & $\begin{array}{r}14 \\
252\end{array}$ & $\begin{aligned} 32 \\
111\end{aligned}$ & 24 & $\begin{array}{l}3 \\
9\end{array}$ & 55 & $\begin{array}{r}5 \\
49\end{array}$ \\
\hline Schenectady, N.Y. & 34 & 28 & 6 & - & - & - & 3 & Houston, lex. & $\begin{array}{r}410 \\
83\end{array}$ & $\begin{array}{r}252 \\
58\end{array}$ & 16 & $\begin{array}{r}24 \\
5\end{array}$ & $\begin{array}{l}y \\
1\end{array}$ & 22 & 49 \\
\hline Scranton, Pa. & 36 & 28 & 7 & 1 & - & - & 3 & Little Rock, Ark. & $\begin{array}{l}83 \\
41\end{array}$ & $\begin{array}{l}58 \\
16\end{array}$ & $\begin{array}{l}16 \\
15\end{array}$ & $\begin{array}{l}5 \\
7\end{array}$ & $\begin{array}{l}1 \\
3\end{array}$ & 3 & $\begin{array}{c}4 \\
-\end{array}$ \\
\hline Syracuse, N.Y. & 153 & 120 & 25 & 6 & - & 2 & 9 & New Orleans, La. & $\begin{array}{r}41 \\
194\end{array}$ & $\begin{array}{r}16 \\
129\end{array}$ & $\begin{array}{l}15 \\
36\end{array}$ & 20 & $\begin{array}{l}3 \\
3\end{array}$ & $\overline{6}$ & 13 \\
\hline Trenton, N.J. & 30 & 21 & 6 & 3 & - & - & 1 & San Antonio, lex. & $\begin{array}{r}194 \\
30\end{array}$ & $\begin{array}{r}129 \\
22\end{array}$ & $\begin{array}{r}36 \\
6\end{array}$ & $\begin{array}{r}20 \\
1\end{array}$ & $\begin{array}{l}3 \\
1\end{array}$ & 6 & $\begin{array}{r}13 \\
3\end{array}$ \\
\hline Utica, N.Y. & 20 & 19 & - & - & 1 & - & 3 & Shreveport, La. & $\begin{array}{r}30 \\
143\end{array}$ & $\begin{array}{l}22 \\
97\end{array}$ & $\begin{array}{r}6 \\
25\end{array}$ & $\begin{array}{r}1 \\
17\end{array}$ & $\begin{array}{l}1 \\
3\end{array}$ & $\overline{1}$ & $\begin{array}{l}3 \\
8\end{array}$ \\
\hline Yonkers, N.Y. & 25 & 17 & 5 & 3 & - & - & 6 & Tulsa, Okla. & & & & 17 & 3 & 1 & 8 \\
\hline E.N. CENTRAL & 2,350 & 1,582 & 497 & 160 & 51 & 59 & 151 & MOUNTAIN & 1,079 & 695 & 171 & 59 & 25 & 19 & 92 \\
\hline Akron, Ohio & 56 & 31 & 16 & 4 & 2 & 3 & 5 & Albuquerque, N.M. & 151 & 105 & 34 & 8 & 1 & 3 & 17 \\
\hline Canton, Ohio & 44 & 33 & 8 & 3 & - & - & 11 & Boise, Idaho & 59 & 42 & 8 & 4 & 4 & 1 & 9 \\
\hline Chicago, III. & 401 & 242 & 104 & 35 & 11 & 9 & 20 & Colo. Springs, Colo. & 65 & 46 & 13 & 3 & 1 & 2 & 4 \\
\hline Cincinnati, Ohio & 72 & $\begin{array}{r}24< \\
49\end{array}$ & 14 & 4 & 2 & 3 & 40 & Denver, Colo. & 100 & 62 & 19 & 7 & 6 & 6 & 12 \\
\hline Cleveland, Ohio & 254 & $\begin{array}{r}49 \\
191\end{array}$ & 47 & $\begin{array}{r}4 \\
10\end{array}$ & 2 & 4 & $\begin{array}{r}4 \\
11\end{array}$ & Las Vegas, Nev. & 191 & 131 & 44 & 12 & 3 & 1 & 9 \\
\hline Columbus, Ohio & 221 & 151 & 39 & 17 & 10 & 4 & 18 & Ogden, Utah & 53 & 45 & 4 & 4 & - & - & 9 \\
\hline Dayton, Ohio & 144 & 99 & 35 & 7 & 3 & - & 11 & Phoenix, Ariz. & 112 & 2 & - & - & - & - & 5 \\
\hline Detroit, Mich. & 227 & 127 & 65 & 22 & 4 & 8 & 14 & Pueblo, Colo. & 43 & 38 & 4 & 1 & - & - & 2 \\
\hline Evansville, Ind. & 57 & 45 & 11 & - & - & 1 & 3 & Salt Lake City, Utah & 168 & 119 & 26 & 10 & 7 & 6 & 17 \\
\hline Fort Wayne, Ind. & 75 & 52 & 12 & 7 & 2 & 2 & 4 & Tucson, Ariz. & 137 & 105 & 19 & 10 & 3 & - & 8 \\
\hline Gary, Ind. & 16 & 6 & 5 & 4 & 1 & - & 1 & PACIFIC & 1,725 & 1,201 & 359 & 104 & 39 & 22 & 129 \\
\hline Grand Rapids, Mich. & 71 & 53 & 13 & 4 & - & 1 & 7 & Berkeley, Calif. & 16 & 9 & 7 & - & - & - & 3 \\
\hline Indianapolis, Ind. & 197 & 132 & 39 & 13 & 4 & 9 & 15 & Fresno, Calif. & 74 & 47 & 16 & 5 & 2 & 4 & 6 \\
\hline Lansing, Mich. & 48 & 30 & 12 & 2 & 2 & 2 & 3 & Glendale, Calif. & 21 & 11 & 7 & 2 & 1 & - & 2 \\
\hline Milwaukee, Wis. & 143 & 94 & 31 & 10 & 3 & 5 & 7 & Honolulu, Hawaii & 75 & 56 & 13 & 3 & 1 & 2 & 4 \\
\hline Peoria, III. & 50 & 36 & 3 & 6 & 2 & 3 & 1 & Long Beach, Calif. & 96 & 69 & 18 & 6 & 1 & 2 & 7 \\
\hline Rockford, III. & 61 & 47 & 10 & 3 & 1 & - & 5 & Los Angeles, Calif. & 374 & 267 & 77 & 18 & 11 & 1 & 42 \\
\hline South Bend, Ind. & 36 & 28 & 6 & 2 & - & - & - & Pasadena, Calif. & $U$ & U & $U$ & $\mathrm{U}$ & U & U & $\bar{U}$ \\
\hline Toledo, Ohio & 94 & 68 & 15 & 5 & 2 & 4 & 6 & Portland, Oreg. & 110 & 75 & 25 & 4 & 2 & 4 & 5 \\
\hline Youngstown, Ohio & 83 & 68 & 12 & 2 & - & 1 & 5 & Sacramento, Calif. & 185 & 119 & 43 & 16 & 6 & 1 & 7 \\
\hline W.N. CENTRAL & 509 & 357 & 96 & 31 & 11 & 14 & 42 & San Diego, Calif. & 172 & 123 & 34 & 9 & 5 & 1 & 16 \\
\hline Des Moines, lowa & 46 & 35 & 7 & 3 & 1 & 14 & $\begin{array}{r}42 \\
3\end{array}$ & San Francisco, Calif. & U & U & $U$ & $U$ & U & $U$ & $U$ \\
\hline Duluth, Minn. & 47 & 33 & 10 & 1 & 2 & 1 & 4 & San Jose, Calif. & 188 & 132 & 38 & 12 & 3 & 3 & 9 \\
\hline Kansas City, Kans. & 13 & 8 & 3 & 2 & - & - & $\begin{array}{l}4 \\
2\end{array}$ & Santa Cruz, Calif. & 43 & 35 & 6 & 2 & - & - & 2 \\
\hline Kansas City, Mo. & 66 & 40 & 16 & 6 & 3 & 1 & 4 & Seattle, Wash. & 193 & 116 & 49 & 20 & 5 & 3 & 13 \\
\hline Lincoln, Nebr. & 58 & 49 & 6 & 3 & - & - & 7 & Spokane, Wash. & 72 & 59 & 12 & - & - & 1 & 8 \\
\hline Minneapolis, Minn. & 67 & 43 & 12 & 2 & 2 & 8 & 4 & Tacoma, Wash. & 106 & 83 & 14 & 7 & 2 & - & 5 \\
\hline Omaha, Nebr. & 71 & 46 & 17 & 5 & 2 & 1 & 10 & TOTAL & $12,731^{\pi}$ & 8,490 & 2,670 & 890 & 287 & 275 & 886 \\
\hline St. Louis, Mo. & U & U & U & U & $\bar{U}$ & $\mathrm{U}$ & $U$ & & & & & & & & \\
\hline St. Paul, Minn. & 61 & 47 & 11 & 2 & - & 1 & 4 & & & & & & & & \\
\hline Wichita, Kans. & 80 & 56 & 14 & 7 & 1 & 2 & 4 & & & & & & & & \\
\hline
\end{tabular}

\section{U: Unavailable. $\quad$-:No reported cases.}

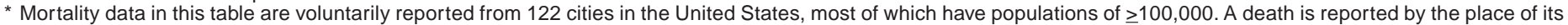
occurrence and by the week that the death certificate was filed. Fetal deaths are not included.

+ Pneumonia and influenza.

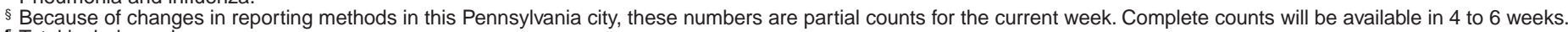
" Total includes unknown ages. 
The Morbidity and Mortality Weekly Report (MMWR) Series is prepared by the Centers for Disease Control and Prevention (CDC) and is available free of charge in electronic format and on a paid subscription basis for paper copy. To receive an electronic copy each week, send an e-mail message to listserv@listserv.cdc.gov. The body content should read SUBscribe mmwr-toc. Electronic copy also is available from CDC's World-Wide Web server at http://www.cdc.gov/mmwr or from CDC's file transfer protocol server at ftp://ftp.cdc.gov/pub/publications/mmwr. To subscribe for paper copy, contact Superintendent of Documents, U.S. Government Printing Office, Washington, DC 20402; telephone 202-512-1800.

Data in the weekly MMWR are provisional, based on weekly reports to CDC by state health departments. The reporting week concludes at close of business on Friday; compiled data on a national basis are officially released to the public on the following Friday. Address inquiries about the $M M W R$ Series, including material to be considered for publication, to Editor, MMWR Series, Mailstop C-08, CDC, 1600 Clifton Rd., N.E., Atlanta, GA 30333; telephone 888-232-3228.

All material in the MMWR Series is in the public domain and may be used and reprinted without permission; citation as to source, however, is appreciated.

All MMWR references are available on the Internet at http://www.cdc.gov/mmwr. Use the search function to find specific articles.

Use of trade names and commercial sources is for identification only and does not imply endorsement by the U.S. Department of Health and Human Services.

References to non-CDC sites on the Internet are provided as a service to MMWR readers and do not constitute or imply endorsement of these organizations or their programs by CDC or the U.S. Department of Health and Human Services. CDC is not responsible for the content of these sites. URL addresses listed in MMWR were current as of the date of publication.

触U.S. Government Printing Office: 2004-633-140/69161 Region IV ISSN: 0149-2195 